\title{
A Review of Groundwater Arsenic in the Bengal Basin, Bangladesh and India: from Source to Sink
}

\author{
Madhumita Chakraborty $^{1}$ - Abhijit Mukherjee ${ }^{1,2} \cdot$ Kazi Matin Ahmed $^{3}$
}

Published online: 4 December 2015

(C) Springer International Publishing AG 2015

\begin{abstract}
The groundwater of the Bengal basin, in Bangladesh and West Bengal state of India, is found to be severely polluted by non-point sourced, geogenic arsenic (As), which has been regarded as the largest public health concern in the human history. The geomorphology and geology of the aquifers play very important role in the three dimensional existence of the As in the groundwater. The provenance of the groundwater As of Bengal basin may be hypothesized to be sourced to the Himalayan orogenic belt, where the contaminant might have originated by deep-seated tectono-magmatism and subsequently introduced to the surficial system by exhumation. Later, sedimentary processes transported the As-laden sediments from the orogenic belt to the peripheral foreland basin of Bengal where, under conducive biogeochemical environment, the As is released from the solid-phase to the circulating groundwater. Ferric hydroxides and pyrite are considered to be the two most important host minerals for As, although clay minerals may also act as important substrates for the sorbed As. The mobilized As then exists in the groundwater until a suitable geochemical sink is available. The mobilization process may be related to reductive-dissolution of metal oxides and hydroxides that exist in the unconsolidated sediments of the Bengal basin. Other mechanisms like pyrite oxidation, redox cycling in surficial
\end{abstract}

This article is part of the Topical Collection on Sediment and Other Pollutions

\section{Abhijit Mukherjee}

amukh2@gmail.com

1 Department of Geology and Geophysics, Indian Institute of Technology Kharagpur, Kharagpur, WB 721302, India

2 School of Environment Science and Engineering, Indian Institute of Technology Kharagpur, Kharagpur, WB 721302, India

3 Department of Geology, University of Dhaka, Curzon Hall Campus, Dhaka 1000, Bangladesh soils, and competitive ion exchange are also accepted as potential mechanisms for arsenic mobilization, and multiple processes may simultaneously contribute to the mobilization of As. The processes are significantly complicated by redox disequilibria in the Bengal basin aquifers. These inorganic processes may have been significantly catalyzed and accentuated by microbially mediated activities. The tertiary source of groundwater As is the irrigation return flow from the agricultural fields.

Keywords Arsenic $\cdot$ Groundwater $\cdot$ Bengal $\cdot$ India . Bangladesh

\section{Introduction}

The Bengal basin houses more than $2 \%$ of the world's population, with an areal extent of about $200,000 \mathrm{~km}^{2}[1,2]$ and represents the most serious arsenic contamination in groundwater identified globally $[3,4]$. The Bengal basin includes most of Bangladesh and some parts of West Bengal, Assam and Tripura. The Bengal basin is drained by the Ganges-BramhaputraMeghna river system and represents the world's largest fluviodeltaic basin $[1,2,5]$. The syn-orogenic sediment pile within the basin is upto $22 \mathrm{~km}$ thick and is of Cenozoic age [1, 6, 7, 25].

The large-scale shift from inconsiderately used and polluted surface water to groundwater usage during the early 1970s, posed groundwater as the major source of pollution-free drinking water and also as a perennial source of water for irrigation within the basin. This major shift from the surface water to the groundwater usage resulted in higher rate of access to safe drinking water and improved food security, due to higher rice production during the dry season. At the same time, despite the positive impacts, extensive groundwater usages resulted in inadvertent exposure of a significant proportion of the population to high 
arsenic in groundwater, leading to widespread cases of arsenicosis and other health risks.

There is a huge volume of literature reviews on arsenic [3, 4, $8,9]$. But none of these individual reviews circumscribe all of the processes and phenomena that control the fate of arsenic within the aquifers of the Bengal basin. This review looks at the arsenic problem in a holistic way, from the primary to local sources and incorporates all the natural and anthropogenic processes and factors that influence the mobilization, transport and sequestration of arsenic in the aquifers of the basin. It encompasses all the factors, e.g., the primary provenances of arsenic in the orogenic belts, to the alluvial aquifers serving as local repository of arsenic to be mobilized under conducive hydrogeochemical conditions, which can further be re-circulated under anthropogenic influence. The review also deals with all the geological, geomorphological, hydrogeological and anthropogenic factors that affect the fate of arsenic in the groundwater of the Bengal Basin.

The aim of this review is to make a comprehensive study including the various processes and factors that operate at different degrees in different parts of the basin to control the mobilization, transport and sequestration of arsenic in the ba$\sin$. The review paper treats the Bengal basin as one geological unit across the geopolitical boundary of Bangladesh and Indian state of West Bengal with similar geological, hydrological and biogeochemical processes that control the fate of arsenic in the groundwater of the basin.

\section{The Threat of Groundwater Arsenic to Public Health and Its Chronology}

The first occurrence of arsenic concentration exceeding $50 \mu \mathrm{g} / \mathrm{L}$ (national permissible limit for arsenic in drinking water in both Bangladesh and West Bengal) was discovered in some tube wells in North 24 Parganas district of West Bengal in 1978 [9, 10]. In 1993, the Department of Public Health Engineering (DPHE), Bangladesh first found high arsenic concentrations in the groundwater of Nawabganj, Bangladesh [3, 11, 12]. Following this, arsenic was found in a number of other areas in West Bengal [9], as well as in Bangladesh. Kinniburgh et al. [11] reported a rapid increase in arsenic concentrations around 1995, which is in coincidence to the explosion in the use of groundwater for irrigation.

Thirty to thirty-five million and 77 million people are reported to be exposed to arsenic concentrations exceeding 50 and $10 \mu \mathrm{g} / \mathrm{L}$, respectively, in Bangladesh, whereas in West Bengal about 15 and 50 million people are exposed to such high arsenic in drinking water, exceeding the 50 and $10 \mu \mathrm{g} / \mathrm{L}$ standards for arsenic, respectively [3, 4, 9, 11, 13-15]. Smith et al. [16] reported this to be 'the largest poisoning of a population in history'. Drinking water and food prove to be the two most significant sources of arsenic intake in the human diet. There is an intricate relation between the spatial distribution of the arsenic patients and their health problems with the spatial variation of arsenic in drinking groundwater and rice $[17,18]$. Rice is the largest dietary source of arsenic in areas where drinking water does not contain high concentrations of arsenic [17]. The resultant health problems were first identified in West Bengal in 1984 [19] and in Bangladesh in 1993 [4]. The most common health effects of arsenicosis include retarded development in children, cases of skin disorders (melanosis, leucomelanosis, keratosis, hyperkeratosis and skin cancer), non-pitting edema, gangrene, hypertension, internal cancers (bladder, lung, kidney and liver), peripheral vascular disorders, ischemic heart disease, cardiovascular diseases, restrictive pulmonary disease, non-cirrhotic portal fibrosis, respiratory problems, hypertension and diabetes mellitus $[3,8,17,20]$. What worsens the situation is that the signs of arsenicosis appear very slowly [3]. The WHO safe limit for arsenic in drinking water was provisionally reduced to $10 \mu \mathrm{g} / \mathrm{L}$ from $50 \mu \mathrm{g} / \mathrm{L}$ in 1993 [4]. The recommendation for the 'safe limit' is mostly based on the awareness about its toxicity and ability to quantitively measure it, and thus, most of the developing countries (e.g. India and Bangladesh) still hold the national safe limit of $50 \mu \mathrm{g} / \mathrm{L}$ due to the lack of facilities to measure lower concentrations $[4,9]$. Arsenic in groundwater was not routinely analyzed until for the past few decades $[4,9]$.

\section{Spatial and Temporal Extent of Groundwater Arsenic}

\section{Spatial Extent of Groundwater Arsenic and Its Variability}

Arsenic concentrations have been found to widely vary over parts of the basin, with a range of $<0.5$ to $>4600 \mu \mathrm{g} / \mathrm{L}[4,6,9$, 13, 21-24]. The mean and the median arsenic concentration values of the sampled tube wells in Bangladesh are reported to be 55-60 and $4 \mu \mathrm{g} / \mathrm{L}$, respectively (assuming the arsenic values for wells below detection limit to be half of the detection limit) $[11,13]$. Out of about 6 to 11 million tube wells in Bangladesh $\sim 25 \%$ of the tube wells are reported to contain more than $50 \mu \mathrm{g} / \mathrm{L}$ of arsenic and $42 \%$ of the tube wells exceeded the $10 \mu \mathrm{g} / \mathrm{L}$ standard for arsenic [11, 13]. Ahmed et al. [6] reported that about 3 million tube wells in Bangladesh with a filter depth between 10 and $50 \mathrm{~m}$, contain arsenic concentrations above $50 \mu \mathrm{g} / \mathrm{L}$. Eight districts in West Bengal are known to be arsenic contaminated, out of which five districts, namely Maldah, Murshidabad, Nadia and North and South 24 Parganas (including some parts of Kolkata), are heavily contaminated with arsenic [9, 20]. BGS/DPHE [13] reported arsenic contamination in 53 districts of Bangladesh, out of which 12 districts (namely, Chandpur, Munshiganj, Gopalganj, Madaripur, Noakhali, Satkhira, Comilla, Faridpur, Sharaitpur, Meherpur, Bagerhat and Laxmipur) are declared to be the worst-arsenic-affected ones. The southern and the eastern parts of Bangladesh are the worst arsenic contaminated areas with about $90 \%$ of contaminated wells in some districts, while it is as low as $1 \%$ in other districts located within the Pleistocene uplands of the Madhupur and the Barind tracts of northern Bangladesh [4, 13] (Fig. 1). The variation in arsenic concentrations between 
Fig. 1 Geomorphologic map of the Bengal basin and the surrounding areas, demonstrating the extent of elevated arsenic in groundwater and its relation to the topography and physiography of the basin (modified from $[2,25]$ )

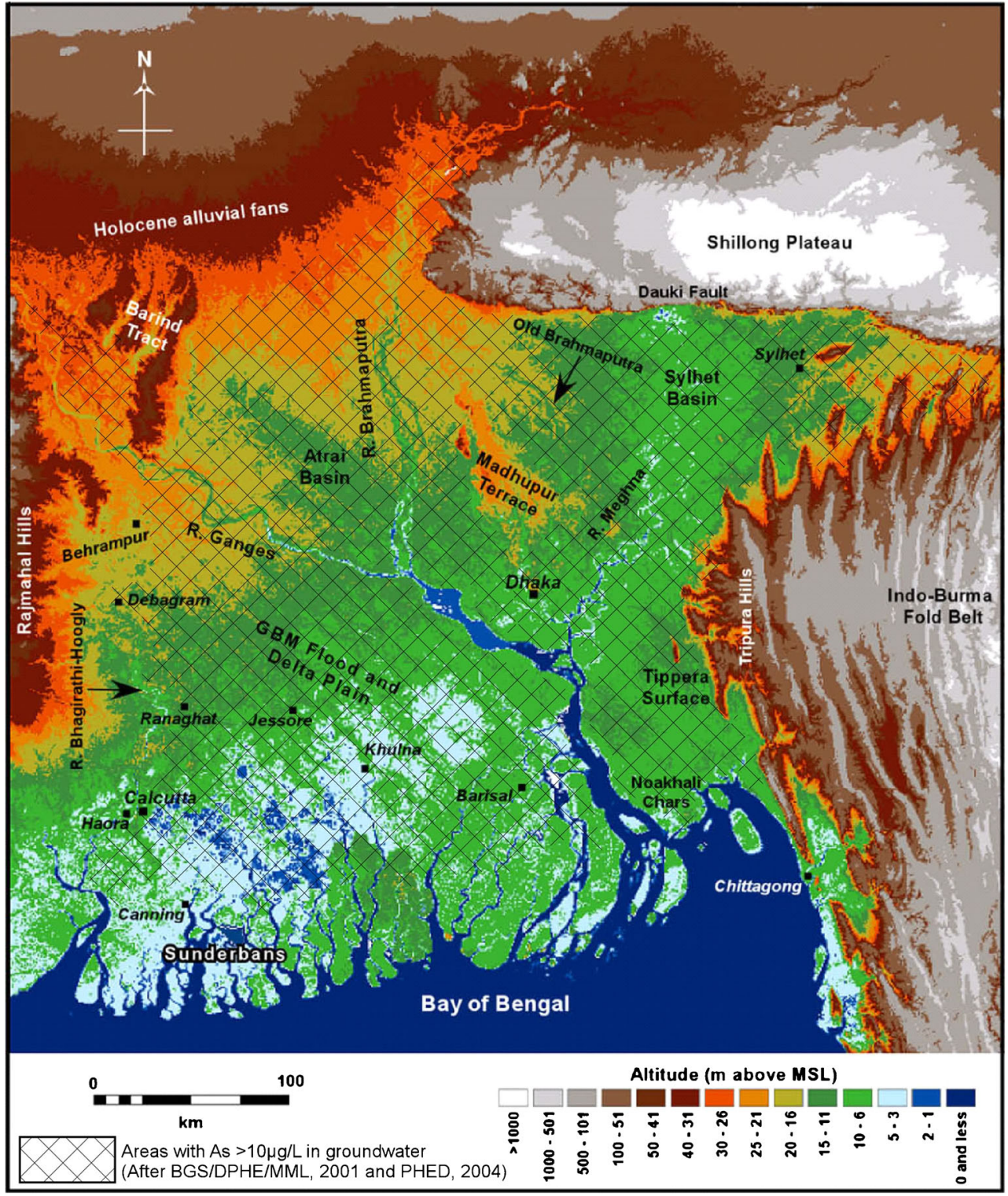

the uplands to the north and the delta plains to the south can be attributed to the grain size of the sediments, presence or absence of a surficial confining layer, abundance of iron oxide, the redox state of the aquifers and rates of groundwater flushing [11, 13]. Isolated 'hot spots' of arsenic are located in the northeastern, northwestern, southwestern and north-central parts of Bangladesh [6]. More than about $60 \%$ wells in the Ganges-Brahmaputra flood and delta plains are arsenic contaminated, while within the shallow aquifers in the Meghna river system and the coastal plains $80 \%$ wells are heavily contaminated with arsenic [6]. The southern delta plains of the GangesBramhaputra-Meghna (GBM) river system in Bangladesh are more arsenic enriched than the northern flood plains $[6,26]$.

The arsenic concentrations show a wide range of spatial variability, even at a local scale (well-to-well variability), which makes it very difficult to predict the arsenic concentration of the unsampled wells, even with the knowledge of the arsenic concentrations from the surrounding tested wells $[6,8$, 13, 20, 27-31]. The high arsenic zones are found to be occurring as patches in small spatial scales and even in vertical profiles. According to Harvey et al. [26, 32], an intricate mosaic of recharge and discharge zones drive the groundwater through a very complex transient flow path, where the distribution of the dissolved arsenic corresponds to the spatial disposition of the groundwater flow paths. Kinniburgh et al. [11] and Van Geen et al. [29] stated that the complexity in relation to the distribution of arsenic seems to follow a pattern if both the depth and the geological setting are taken into consideration. Moreover, because of the weak correlation of arsenic to other trace metals, individual wells must be tested for arsenic [20]. 


\section{Depth Variation}

Only 1 and $5 \%$ of the deep wells in Bangladesh exceed the 50 and $10 \mu \mathrm{g} / \mathrm{L}$ standards for arsenic, respectively, while these values are 27 and $46 \%$ for the shallower wells (the boundary of the shallower and the deeper wells being taken at $150 \mathrm{~m}$ ), suggesting that the arsenic problem is much more intensified in the shallower waters than in the deeper parts [11, 13] (Fig. 2). The bounding depth between the shallow and the deep aquifer is controlled by the local geology, including the aquifer characteristics and the intermediate confining clay units [11].

The regional depth variance of arsenic concentrations tends to follow a bell-shaped curve with the peak concentration at the depth of 15-30 m in Bangladesh [11]. Arsenic concentrations in Bangladesh are reported to increase at first, up to a depth of 10-20 m and then decrease from 50 to $150 \mathrm{~m}$, although the precise depth of decline is not clear [11]. Van Geen et al. [29] also reported an initial increase in the number of arsenic contaminated tube wells in their study area in Bangladesh, from $25 \%$ at $8-10 \mathrm{~m}$ to $75 \%$ between 15 and $30 \mathrm{~m}$, followed by a gradual decline with $10 \%$ arsenic contaminated tube wells at $90 \mathrm{~m}$. The highest arsenic contamination is confined within the middle unit (approximately $6-70 \mathrm{~m}$ in the western part of the basin) of the late Pleistocene-Holocene sedimentary sequence beneath the flood and the delta plains, also called the 'arseniferous unit' of the Bengal basin [11, 35, 36]. Mukherjee and Fryar [37] reported the highest concentrations of total and reduced arsenic (and iron) to be at a depth of about $100 \mathrm{~m}$ and an increase of $\mathrm{As}(\mathrm{III}) / \mathrm{As}_{\text {total }}$ with depth within West Bengal. Harvey et al. [26, 32] related the peak concentration of arsenic to the mixing zone of older waters to younger recharge, as evidenced from the head data, ${ }^{18} 0$ profiles, tritium concentrations and aquifer architecture. The authors suggested that these bell-shaped vertical profiles are typical of a plume migration and may result from a large lateral component of flow, typical of flat lying alluvial aquifers, along with a surficial source of organic carbon which mobilizes the arsenic. The authors also suggested that there can be a relationship between the depth where the aquifer is highly conducive and the depth of the peak concentration of arsenic, as evidenced by the highest number of tube wells withdrawing water from a depth of 10-50 $\mathrm{m}[13,32]$, but this is yet not confirmed. Van Geen et al. [29] suggested that though such correspondence is intriguing, it does not necessarily establish any relation between the arsenic concentrations and the density of wells. Although the typical bell-shaped depth profiles may be considered to be a local phenomenon and may not hold good at larger scale, decreasing concentrations of arsenic with depth seems to be regionally true [26, 32]. Harvey et al. [38] reported a decrease in arsenic concentration with depth, with the peak concentration at a depth of $30-40 \mathrm{~m}$ at their study site in Bangladesh. McArthur et al. [28] reported the vertical gradients of arsenic concentrations to be ranging up to $200 \mu \mathrm{g} \mathrm{L}^{-1} \mathrm{~m}^{-1}$ within the West Bengal part of the basin.

This may lead to a probable explanation for different arsenic concentrations between nearby wells, owing to their different depths of withdrawal [26, 32], in addition to the complex pattern of variations of sediment characteristics between the wells. Van Geen et al. [29] reported that, although arsenic concentrations are greater than $50 \mu \mathrm{g} / \mathrm{L}$ in majority of wells shallower than $30 \mathrm{~m}$ and vice versa in Bangladesh, a significant fraction of wells do not fit this pattern. Ahmed et al. [6] thus argued that the groundwater arsenic concentration is not a function of depth itself, but is a result of the facies architecture of the alluvial sediments. The variation of arsenic concentrations between the shallow and the deeper aquifers can be attributed to the factors like the total arsenic concentration in the sediments, the grain size and the sorption capacity of the sediment grains, the redox condition of the aquifers, the period of groundwater flushing and the conditions of artificial groundwater withdrawal. The deeper Pleistocene aquifer has experienced longer period of flushing under greater hydraulic heads which has effectively flushed much of its arsenic relative to the young (5-10 ka) Holocene sediments [20, 39]. The arsenic concentrations in the near surface sediments are quite low due to the oxidized nature of the sediments, inflow of young recharging groundwater and higher rate of flushing, resulting in low concentrations of arsenic in dugwells $[11,13]$.

Moreover, Mukherjee et al. [9] reported that about $60 \%$ of the deep wells in West Bengal have arsenic concentrations more than $10 \mu \mathrm{g} / \mathrm{L}$, in contrast to only $5 \%$ in Bangladesh [13] and they attributed this to the difference in evolution between the West Bengal stable shelf part and the Bengal foredeep part of the Bangladesh and also to the landuse patterns.

\section{Temporal Variation}

Although arsenic concentrations in wells have been reported to vary over a short period of time, systematic long-term monitoring to characterize the patterns and trends of such temporal variations is still lacking. BGS/DPHE [13] carried out arsenic monitoring in three piezometer nests at different locations in Bangladesh and concluded that there was no consistent pattern of change in the concentrations over the monitoring period of 3 years. One consensus that has been achieved in all these years is that, in general, temporal variations in arsenic concentration of different wells are limited, and that the variations are the highest in the shallowest depths and the concentrations seem to be quite stable in deeper parts, owing to the fact that the groundwater flow is much more vigorous along with larger inputs in the shallower depths of the aquifers. Dhar et al. [40] reported a variation of $<30 \%$ in the arsenic concentrations of the wells shallower than $30 \mathrm{~m}$, whereas for wells deeper than $30 \mathrm{~m}$, often capped by clay layers, the variance was as low as $<10 \%$ in their study site in Bangladesh. 
Fig. 2 Variations in the vertical distribution of groundwater arsenic concentrations with depth in West Bengal and Bangladesh (prepared from [6, 8, 13, 30, 33, 34])

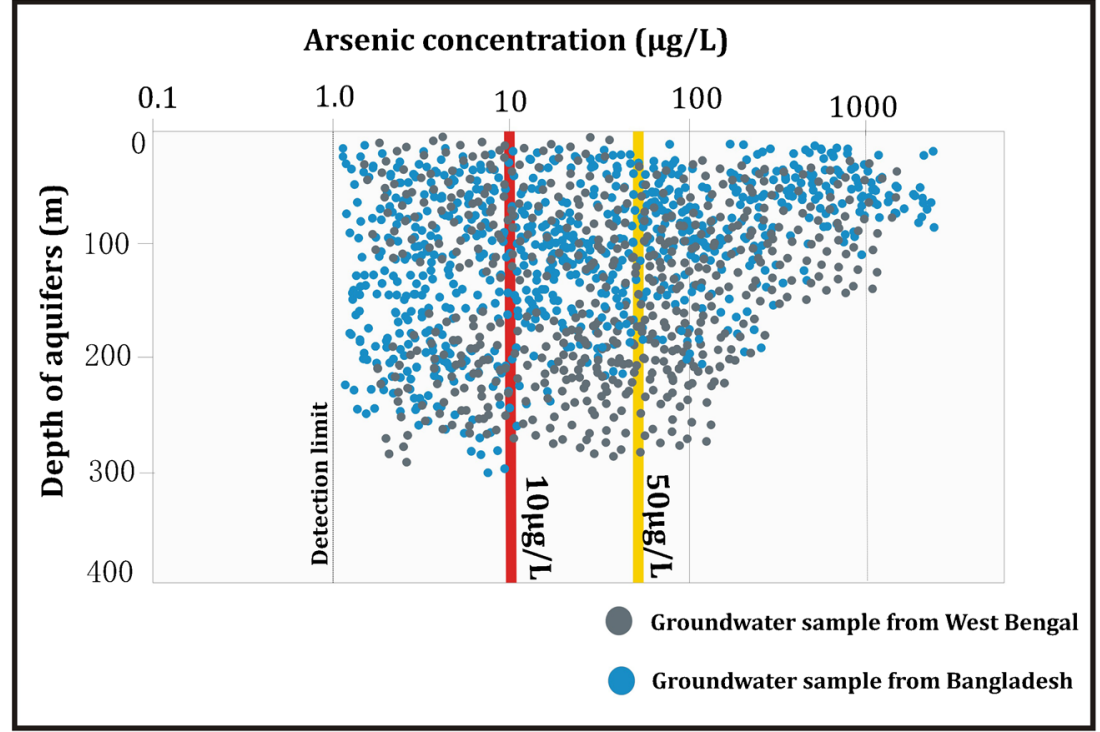

Ravenscroft et al. [41] reported no deterioration in groundwater quality in deep wells $(>150 \mathrm{~m})$ over a monitoring period of 13 years in Bangladesh and hence, inferred that the deeper aquifers do not show any change in water quality from predevelopment conditions.

Arsenic concentrations are reported to exhibit various types of trends in relation to temporal variations. Some wells are reported to show statistically significant trends, while others show irregular and random changes in concentrations [13, 29, 40, 42-44]. Such variations in the concentration of arsenic in groundwater have been attributed to changes in pumping rate during the course of a day, seasonal variations in recharge and precipitation, seasonal oscillations in redox processes affecting the $\mathrm{Fe}$ and $\mathrm{S}$ cycling, irrigational abstractions, head gradients, aquifer flushing, long-term changes in climate and groundwater levels, changes in pumping regimes and depth of abstraction in relation to the gradual reduction of water level due to pumping and entrainment of high As shallow groundwater into a deeper low As well due to construction defects $[20,44]$. The trends can be either increasing or decreasing over both long and short time periods or may show consistent seasonal oscillations with concentrations hitting the minima at either wet seasons or dry seasons, depending on the hydrogeological controls. Tareq et al. [45] reported no significant fluctuation in groundwater chemistry due to seasonal variations, barring few random changes in their study area in Bangladesh. CGWB [21], on the other hand, reported a seasonal variation in groundwater arsenic concentrations in West Bengal, with minima during the post-monsoon period which is thought to be due to dilution of groundwater arsenic by monsoonal recharge. Cases of an overall decrease in arsenic concentration in wells over time or during wet seasons can be attributed to the concept of dilution and/or aquifer flushing [28, 40, 44, 46, 47]. Mandal et al. [48] claimed that the deeper tube wells which were once arsenic free, may get contaminated over the years in areas where the shallower tube wells are arsenic contaminated. However, such claims need a lot more robust data to support the hypothesis. If such temporal trends are found in deeper groundwater then it can be due to the hydraulic connectivity between the aquifers, and groundwater mixing from different depths due to inadequate sealing of tube wells, construction failures or multiple screening at different depths [20]. Long-term monitoring is needed to establish the seasonal and long-term changes in concentrations of arsenic for mitigation efforts [20]. A linear relationship between shallow groundwater age $(<30$ years and $<20 \mathrm{~m})$ and dissolved arsenic concentrations, reported by Stute et al. [47], was hypothesized to be sustained by a constant rate of arsenic release in the shallower aquifers of Bangladesh, a process that is decoupled from change in redox states of the aquifers [40]. However, various scientific literatures have reported a wide range of arsenic release rates $[38,49]$, and the concentrations of dissolved arsenic are controlled by the biogeochemical conditions encountered along the flow length, the age of the groundwater in connection to the development of a quasi-equilibrium condition between the solid phase arsenic and the dissolved arsenic, the gradual flushing of arsenic from the aquifers and groundwater mixing [47].

\section{Sources of Arsenic}

Arsenic is a trace element in the earth's crust (e.g. [50-52]) with an average concentration in the range of $1-2 \mathrm{mg} / \mathrm{Kg}[4$, $50,51,53]$. The concentration of arsenic in the Bengal aquifer sediments range from 0.4 to $40 \mathrm{mg} / \mathrm{Kg}[4,11,13,33,45$, 55-57], making up for an average which is slightly higher than that for the average unconsolidated sediments found to be in the range of $2-10 \mathrm{mg} / \mathrm{Kg}$ [4]. The sediments of the Bengal basin are not reported to be exceptionally enriched in 
arsenic [32, 55, 57]; concentrations of arsenic in sand are found to be generally less than $10 \mathrm{mg} / \mathrm{Kg}$ and concentrations are less than $100 \mathrm{mg} / \mathrm{Kg}$ for clay and peat layers [26, 32, 38]. However, very high and even toxic concentrations of arsenic have been found in the groundwater of the Bengal aquifer system.

There has been a persistent search for the precise sources of arsenic in the Bengal aquifer system, e.g. the Rajmahal Traps and the Rajmahal Basin of eastern Bihar were thought to be prospective sources of high arsenic minerals [11] until it was proposed that the aquifer sediments in high arsenic groundwater areas are not unusually high in arsenic content, but it is the hydrologic and the biogeochemical environment that triggers the mobilization of arsenic from these sediments under the condition of low flushing rates, leading to high arsenic groundwater (e.g. [4, 11, 32, 51, 52]).

On the other hand, Ravenscroft et al. [58] showed that the arsenic-enriched aquifers are located close to young fold mountain belts. Mukherjee et al. [51] observed that the provinces with elevated arsenic concentrations around the world (following $[4,58,59]$ ) are located in or near large sedimentary basins adjacent to major orogenic belts, indicating the role of a regional geological process controlling the arsenic concentrations. Thus, though the 'source of arsenic' is not considered to be as critical a factor as the 'hydrologic' and 'biogeochemical environment' in producing high arsenic groundwater, the regional scale geodynamic and geochemical processes seem to influence arsenic concentrations in groundwater. The regional extent of arsenic contamination in the Bengal aquifer system indicates a non-point geogenic source of the arsenic in the aquifers [6, 36, 48, 51, 54, 57], although possibilities of anthropogenic activities (excessive groundwater abstraction from the shallow and the deeper depths of the aquifer, irrigational pumping, use of fertilizers, etc.) influencing the arsenic concentrations cannot be completely ignored [33].

\section{Primary Sources}

The Bengal basin is a large sedimentary province adjoining the Himalayan mountain belt. Mukherjee et al. [2] defined the Bengal basin as a peripheral foreland basin formed as a result of the subduction of the Indian plate below the Eurasian and the Burmese plate, causing the advent of the Himalayan orogeny, along with lithospheric flexure due to the load of the overriding thrust sheet. Several other workers defined the Bengal basin as a remnant oceanic basin formed as a result of the closure of the Tethys Sea $[1,60,61]$. The major provenances of sediments to the Bengal basin also serve as the primary source of arsenic to the basin. The arsenic contamination map of the Bengal Basin shows that the highest contaminations occur in and around the catchments of the Ganges-Bramhaputra-Meghna river system, strongly indicating the influence of multiple provenances [54] including the arsenic enriched parent rocks of the Himalaya and its foreland, the Indian Shield, the Shillong Plateau and the Burmese arc [1, $15,51]$. Ghosh and De [62] claimed that the RajmahalChotanagpur plateau acts as the provenance for the highly arseniferous sediments of North 24 Parganas (West Bengal), whereas the sediments with relatively low content of arseniferous particles are derived from the Bihar Plateau and the Himalayas. Nickson et al. [56, 57] claimed that the base metal deposits located upstream of the Ganges Plain are too localized and are thus not likely to act as a potential source of arsenic to the basin (as per pers. comm. with S.K. Acharyya et al. [63]). Smedley and Kinniburgh [4] stated that the sediments to the Bengal basin are carried down by the GangesBramhaputra-Meghna river system from the upland Himalayan catchments and the basement complexes situated in the northern and western part of West Bengal. Mukherjee et al. [9] and Mukherjee et al. [15] enlisted a number of potential arsenic sources (from [28, 50, 63-68]) as given in the following:

- The Gondowana coal seams in the Rajmahal trap area and its overlying basaltic rocks, drained by the river Ganges and its tributaries. The arsenic concentrations of the coals were found to be as high as $200 \mathrm{mg} / \mathrm{Kg}$. However, there is a persistent debate on the extent to which the Gondowana coal seams contribute to the Bengal Basin sedimentation.

- Bihar mica-belt is a possible source, with arsenic concentrations ranging from 0.08 to $0.12 \%$.

- Isolated sulfide outcrops in Darjeeling Himalayas, containing about $0.8 \%$ arsenic.

- The outcrops in the upper reaches of the Ganges river system with varying concentrations of arsenic.

- North Bengal tributaries of the Bhagirathi and Padma rivers flowing by the Gorubathan base-metal deposits in the eastern Himalayas, which is thought to be a potential source of arsenic.

- Under euxinic conditions prevailing in the paleochannels of the Bhagirathi and Padma rivers, arsenic occurs as a biogenic deposit.

- Arsenic is present within the fluvial sediments transported from the Himalayas. This is the most widely accepted hypothesis at present.

Volcanoes and fumaroles can act as a major primary arsenic source, but do not seem to contribute to the Bengal Basin arsenic [15]. Moreover, it must also be noted that though all the above listed areas presumably contain arsenic, all of them may not serve as a source of arsenic to the Bengal basin [15, 64]. The discrete sources of arsenic to the Bengal aquifer system are still to be precisely identified.

With the advent of Himalayan orogeny different generations of foreland basins were formed as a result of northward progression of the Indian plate. The Paleocene to Eocene Subathu Formation is cited as the present remnant 
of the oldest foreland basin $[51,69]$. The Neogene-aged Siwalik group of rocks also form paleo-foreland basins, adjoining the Lesser Himalayas. These foreland basins acted as the immediate sediment depo-centres for the eroded Himalayan sediments and thus serve as a secondary arsenic reservoir for the Bengal basin [51, 70-72]. The Siwalik foreland is mostly composed of fluvial fining upward sequence containing greywacke sandstones with some silt and clay, along with a number of hot springs present all along the margin which transport arsenic enriched magmatic water from depths to the surface [51, 73]. Moreover, because of the mineralogy and finer grain size, the Siwalik sediments are high in arsenic which is either present in the $\mathrm{Fe}$ or S-bearing minerals or is strongly adsorbed by the smectitic clays, weathered from the serpentinites [51, 70]. The Himalaya-derived arsenic enriched sediments of the Siwalik basin thus define the source repository of arsenic in the Bengal basin [51] (Fig. 3).

Guilliot and Charlet [70] claimed that the ophiolite in the Indus-Tsangpo suture zone is the primary source of arsenic, which was eventually eroded to the Siwaliks during Miocene and Pleistocene and was subsequently been substantially weathered during Holocene. There is a hypothesis that prior to 11 million years (and may be as late as $5 \mathrm{Ma}$ ), the Greater Himalaya was not uplifted and exposed to the surface to form a hydrological divide $[51,70,74]$. Thus, during the Miocene most of the southerly flowing rivers flowed from the South Tibetan plateau [70] and carried a huge amount of arsenic laden material derived from the Indo-Sangpo suture zone to the Siwalik foreland basin and the proto-Bengal basin [51]. Since $5 \mathrm{Ma}$, the Main Frontal Thrust (MFT) was activated, leading to an upliftment of the Siwaliks accompanied by its rapid erosion [70]. The active tectonic history accompanied by the intense humid climate resulted in scavenging of arsenic from the Siwaliks by the Ganga-Bramhaputra river system to the site of sedimentation towards the Bay of Bengal $[51,70]$. On the other hand, Stanger [72] claimed that the primary source of arsenic is the Quamdo-Simao (QS) volcanic and ophiolitic province situated north of the Namche Barwa syntaxis close to the Indo-Mayanmar border, which was eroded and transported towards the Siwalik foreland basin during Miocene. The river Meghna which originates south-east of the Ganges-Bramhapurta river system, seemingly do not receive any sediment contribution from the Siwaliks. The probable source of arsenic to the Meghna river system is thought to be the ophiolites of the Indo-Burmese suture zone, referred as the QS volcanic and ophiolite province by Stanger [72]. Mukherjee et al. [51] claimed that many north-eastern provinces of India and Bangladesh adjoining the QS volcanic and ophiolite province are enriched in arsenic (e.g. [75]).

Ahmed et al. [6] reported that the provenance studies of the Bengal basin aquifer sediments indicate that they are derived from sedimentary, metasedimentary and metamorphic zones of collisional suture and thrust belts adjoining the recycled Himalayan orogenic provenance. Harvey et al. [32] argued that the original source mineral for arsenic is the sulfides, mostly pyrites, present in the granitic and metamorphic parent rocks in the Himalayas. Since late Pleistocene, the oxidative weathering of the source minerals has led to the release of secondary phases like iron oxides, hydroxides and clay particles in the river sediments accompanied by the transfer of much of the coweathered arsenic from the mafic or sulfide mineral phases to the newly formed secondary phases which effectively sorb a large amount of arsenic to its surface $[8$, $76,77]$ and thus act as a principal source of arsenic to the Bengal basin. However, Polizzotto et al. [78] reported that the aquifers of the Bengal basin contain arsenic bearing pyrite grains. McArthur et al. [28] claimed that, except the provenances adjacent to the Indo-Burmese orogenic range, the surface coatings of sorbed arsenic on $\mathrm{FeOOH}$ are formed by weathering of the crystalline rocks and do not seem to be an relict signature from previous erosional cycles.

The Siwalik foreland is drained by the GangesBrahmaputra river system to the east. Guilliot and Charlet [70] also claimed that the smaller rivers draining the Siwaliks have higher arsenic load than that of the larger rivers originating from the Higher Himalayas. Datta and Subramanian [79] measured the average arsenic concentration of sediments from 'River Ganges to be $2.0 \mathrm{mg} \mathrm{Kg}^{-1}$ (range $1.2-2.6 \mathrm{mg} \mathrm{Kg}^{-1}$ ), from the Brahmaputra river to be $2.8 \mathrm{mg} \mathrm{Kg}^{-1}$ (range 1.4 $5.9 \mathrm{mg} \mathrm{Kg}^{-1}$ ) and from the Meghna River to be $3.5 \mathrm{mg} \mathrm{Kg}^{-1}$ (range 1.3-5.6 $\mathrm{mg} \mathrm{Kg}^{-1}$ )'. Nickson et al. [57] claimed that sedimentation in the Bengal basin has proliferated since the last glacial maxima (about $18 \mathrm{ka}$ ) in the late Pleistocene and was at its peak during the sea level transgression (post $10 \mathrm{Ka}$ ), which provided the accommodation space for the inflowing sediments. In contrast to the deeper Pleistocene sediments which have suffered a long period of oxidative weathering [80], the shallower Holocene sands are mainly derived during the period of extended glaciations resulting in intense physical weathering and erosion of a large amount of immature sediments which are subsequently transported and deposited very rapidly towards the delta front, where they are buried in an anoxic waterlogged condition giving rise to the grey reduced aquifer sediments [28]. These Holocene alluvial and deltaic sediments serve as the dominant source of mobilizable arsenic in the Bengal basin under the prevalence of conducive biogeochemical environment [13, 80, 81]. Mukherjee et al. [51] stated that regional to local scale groundwater flows with 


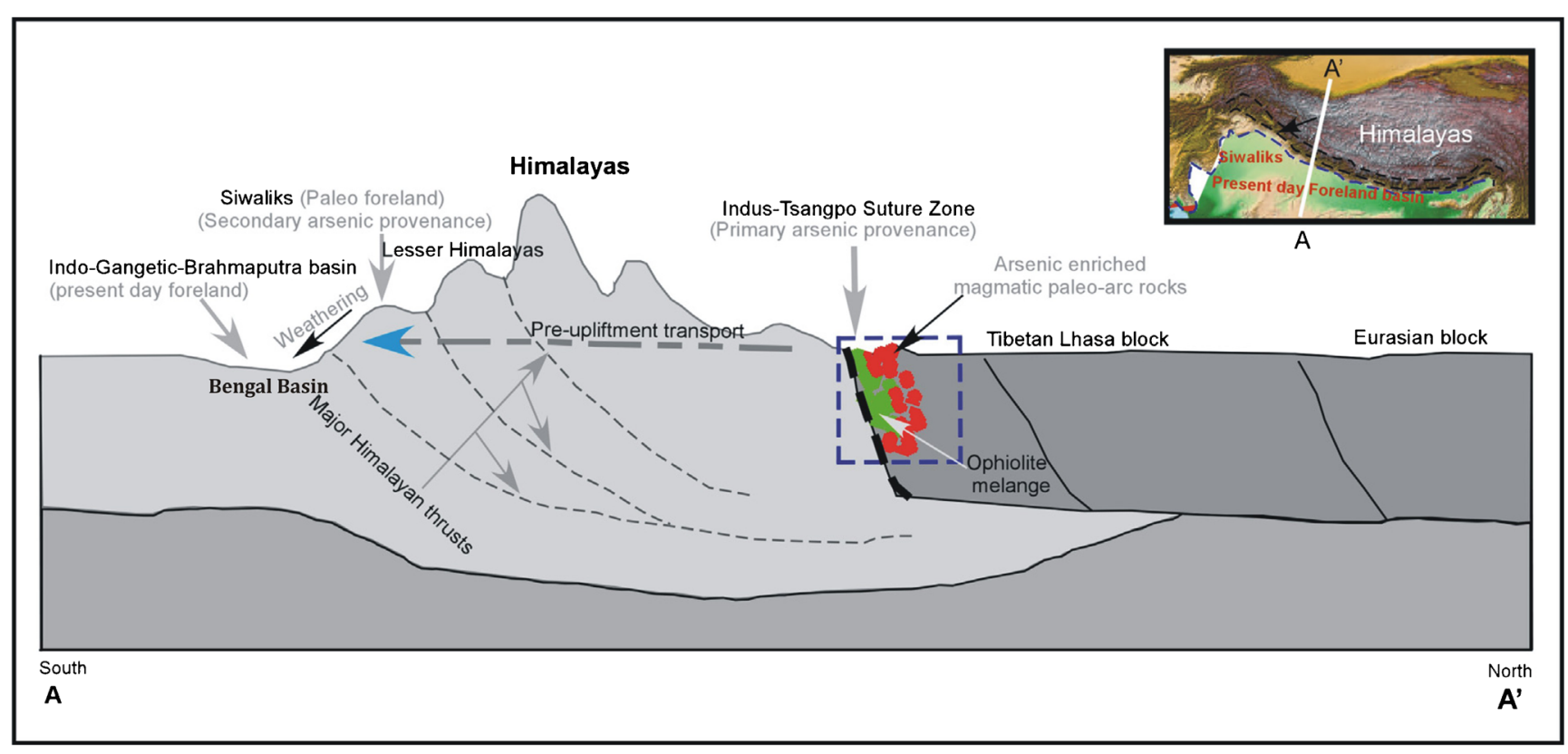

Fig. 3 A hypothetical model of the primary source of groundwater arsenic in the Bengal basin (modified from [51])

recharge zone in the Himalayan foothills transport dissolved arsenic under organic carbon-rich anoxic conditions to the aquifers of the Bengal basin [82].

\section{Secondary Sources}

The arsenic-containing aquifer sediments eroded from the Himalayan source by the Ganges-Bramhaputra-Meghna (GBM) river system, release arsenic to the groundwater under conducive biogeochemical environment. While the arsenic content within the sediments are not unusually high, mobilization of a small fraction of labile arsenic is enough to elevate the arsenic concentrations in the groundwater above its permissible limit [29]. The Bengal basin sediments are broadly composed of channel-fill sands and overbank clays and the evolution of the basin is controlled by fluvial and tidal/estuarine influences [6, 83]. Arsenic concentration in sediments is fairly uniform with depth, with an average concentration in the range of $1-20 \mathrm{mg} /$ $\mathrm{Kg}[4,11,13,33,54]$. The concentrations of arsenic are higher in the silt and clay layers and can range as high as $800 \mathrm{mg} / \mathrm{Kg}$ (generally less than $100 \mathrm{mg} / \mathrm{Kg}$ ) in the surficial clays [78, 84]. Concentrations in sand layers are generally less than $3-10 \mathrm{mg} /$ $\mathrm{Kg}[12,26,32,78]$ and are less than the world average for sedimentary basins $[4,26,32,38,78]$. Peat layers contain high arsenic concentrations [85]. The Pleistocene orange sands are found to contain higher concentrations of solid-phase arsenic than the grey Holocene sands [85].

Solid-phase arsenic in sediments are mostly bound to iron hydroxide and detrital sulfide (e.g. pyrite) minerals [78]. Ironrich mineral phases such as oxides, hydroxides, silicates and carbonates contain substantial amounts of arsenic [85].
Charlet et al. [86] reported the presence of arsenic within carbonates along with micas and amorphous and crystalline iron hydroxides. Less commonly, arsenic is also found within the mafic minerals, such as biotites and amphiboles [3]. Arsenic is also known to sorb on the surfaces of magnetite, green rust, siderite and apatite [26, 32].

Iron(III) hydroxides act as a major host to arsenic [35] in the aquifers of the Bengal basin and under reducing conditions, liberate arsenic to the groundwater. The iron hydroxides are thought to be derived from weathering of the micas, iron sulfides and other primary Fe-bearing minerals [78]. Arsenic can either be adsorbed to the surface of the iron hydroxide molecule, owing to the strong adsorption capacity of some iron hydroxides due to its high specific surface area (which may range upto $600 \mathrm{~m}^{2} / \mathrm{g}$, e.g. ferrihydrite) [87] or can occur within the lattice spaces of iron hydroxide. The adsorption of arsenic to iron hydroxides may occur by anion adsorption phenomena and involve uptake of protons or release of hydroxide ions $[35,88]$. The surface loadings of iron hydroxide to sediments are more abundant in Pleistocene orange sediments than in the Holocene grey sediments, owing to the greater degree of oxidative weathering and transport during the Pleistocene and these iron hydroxides act as sorbents to reduce the concentration of dissolved arsenic in the groundwater [28]. Moreover, the exposure of these sediments to oxidizing conditions has led to the decrease in the content of organic matter and unstable minerals, i.e. amorphous oxyhydroxides and carbonates $[6,13]$, thus yielding low arsenic groundwater. Polizzotto et al. [78], however, questioned the validity of ferric hydroxide as a source of arsenic in the reduced aquifers of the Bengal basin, owing to the fact that 
within the Holocene aquifers purely ferric hydroxide is regionally scarce or absent $[26,38]$. This can however, be explained by the fact that the total surface loading of $\mathrm{FeOOH}$ in the Holocene aquifers has been completely reduced to ferrous ions in most places, in the presence of high organic matter content with the concomitant release of the entire load of sorbed arsenic to the groundwaters, while the $\mathrm{FeOOH}$ completely vanishes from the reduced aquifers giving it a grey colour [28]. Anawar et al. [35] argued that the coexistence of iron hydroxides, organic matter and arsenic can be attributed to the affinity of iron hydroxides to organic matter and arsenic. On the other hand, Polizzotto et al. [78] claimed that the arsenic in sediments of Bangladesh does not bear any contribution from the reduction of ferric hydroxides and rather, the biological reduction reactions within the surface soils and sediments act as a possible source. Although the current aquifer conditions are not conducive for the stability of iron hydroxides within the grey sediments, even a small amount of iron hydroxide can mobilize arsenic to its present degree [26]. Fe(III) hydroxides do not act as an important arsenic repository below a depth of about $100 \mathrm{~m}$ [89].

Pyrite is a common sulfide mineral present in reduced sedimentary aquifers of Bangladesh and West Bengal $[56,57,78$, 89-93] and also in the wood flakes of muddy units [78, 94]. Authigenic framboidal and massive pyrites may contain up to 11,000 and $13,000 \mathrm{mg} / \mathrm{Kg}$ of arsenic respectively, and may account for $70 \%$ of the total arsenic in the deeper aquifers of Bangladesh [89]. Lowers et al. [89] further stated that pyrite primarily forms by two mechanisms: Firstly, by conversion of acid volatile sulfate (AVS) to pyrite and secondly by 'heterogeneous nucleation on surfaces without amorphous FeAsS precursors'. Polizzotto et al. [95] reported that detrital and authigenic sulfide grains contain about $60 \%$ of the total arsenic within the Bangladesh Holocene aquifers. Authigenic framboidal pyrite has been found within clayey sediments in regions of Bangladesh [6]. The framboidal pyrite grains with low arsenic content are found within the upper $20 \mathrm{~m}$ of the grey sediments, while the deeper sediments are dominated by massive pyrites with higher proportion of arsenic [89]. The natural sources of sulfate in the aquifer sediments for subsequent reduction can be attributed to oxidation of detrital sulfides, atmospheric precipitation, river water and sea water fluxes and the lack of pyrite in the shallower sediments (20$100 \mathrm{~m}$ ) is considered to be a result of rapid sedimentation and a low flux of sulfur from the riverine and atmospheric sources [89]. Nickson et al. [57] and McArthur et al. [55] argued that the primary sulfide grains from the source rocks presumably cannot sustain the weathering under the oxidizing and humid conditions of the recent times and thus, most of the pyrites present in the Ganges aquifer system are authigenic, formed during the $\mathrm{SO} 4$ reduction phase of diageneis or microbial sulfogenesis. Nickson et al. [57] further argued that the formation of authigenic pyrite is also limited by the low concentration of sulfate in the fresh recharging waters ( $<20 \mathrm{mg} / \mathrm{L}$ for the water recharging the Ganges aquifers). Although arsenic is found mostly in authigenic pyrite, arsenian pyrite is also present in parts of the deeper aquifer sands in the Bengal aquifer system, however in lesser abundance [96]. Arsenian pyrite has also been reported within the fluvial sediments of West Bengal [91-93]. Polizzotto et al. [78] argued that, depending on the grain size, the oxidation states and the correlation of arsenic with the chalcophiles like $\mathrm{Cu}$ and $\mathrm{Zn}$, some of the sulfide minerals seem to be of Himalaya-derived detrital origin which have suffered deposition and burial before its complete oxidation and concluded that both authigenic sulfide grains (grain size ranging from 10 to $35 \mu \mathrm{m}$ ) and detrital sulfide grains (grain size is about $100 \mu \mathrm{m}$ ) are found in the reduced Holocene and the oxidized Pleistocene aquifers of Bangladesh. Fazal et al. [97] reported that arsenopyrite acts as the primary host to arsenic in the Bengal Basin. Several workers suggested that pyrite grains are very scare in the sediments of Ganges delta [35, 57, 92]. Anawar et al. [35] reported that the sulfur content in Ganges delta is low on average, although peat soil, clayey silts and silty sands contain appreciable amount of arsenic where it occurs as coatings on the pyrite grains. Polizzotto et al. [78] defined two dominant arsenic pools in the aquifers of Bangladesh, namely the arsenic in the sulfide minerals making up for a major part of the total solid phase arsenic and the easily extractable, weakly sorbed arsenic. The arsenic sorbed onto the sulfide grains stay immobilized under reduced aquifer conditions, or even if mobilized under oxidizing conditions are subsequently sequestered to ferric hydroxides $[35,55,76$, 78]. Thus, pyrite present in the aquifers of the Bengal basin acts as a sink rather than a source $[35,55]$.

The arsenic concentrations in soils are found to be as high as $40 \mathrm{mg} / \mathrm{Kg}$ at the surface [78]. Meharg and Rahman [98] attributed these high concentrations of arsenic in soils to be at least partly due to the irrigation return flow. Ali et al. [99] however, reported that the arsenic concentrations in soils were already higher, even prior to the onset of irrigational pumpimg. Stummeyer et al. [100] reported that the concentration of arsenic in the suspended sediments of river Ganges near Bay of Bengal is $15 \mu \mathrm{g} / \mathrm{g}$. On the other hand, Breit et al. [84] reported arsenic concentrations as high as $800 \mu \mathrm{g} / \mathrm{g}$ in the near-surface arsenic-enriched ferric hydroxide sediment layers. Polizzotto et al. [78] argued that irrigation return flow does not alone contribute to such high arsenic concentrations in the surficial layers and attributed it to the aggregation from the recently deposited sediments. The authors thus concluded that the high arsenic concentration in the soils is the result of the use of groundwater for irrigation as well as the continuous inflow of arsenic laden sediments to the surficial soil system. Polizzotto et al. [78] proposed that the dominant source of arsenic in the groundwater is the 
surficial sediments which undergo seasonal redox cycling resulting in the mobilization.

Several studies reported that clays act as sites of sorption for arsenic in the aquifer system [12, 35, 91, 101]. Organic matter-rich fine-grained shales and clays in the Bengal basin are found to be highly enriched in arsenic [9, 35, 102-104]. However, some researches negated the importance of clay as a potential adsorbent for arsenic and emphasized on the iron oxide-coated sand and mica grains present in the sediments (e.g. [105-107]). Phyllosilicates may also serve as an important source of arsenic [107-109].

Arsenic in the basin is not connected to any marine source, as it is evident from the lack of correlation between the arsenic and the $\mathrm{Na}^{+}$and $\mathrm{Cl}^{-}$ions. The mineral phases within the aquifer system which contain arsenic or are capable of retaining arsenic, act as arsenic sinks and desorption from or dissolution of these sinks under conducive biogeochemical environment mobilize arsenic to the groundwater [85].

\section{Tertiary/Irrigational Re-circulation}

The arsenic concentrations in the soils are found to be higher than in the aquifer sediments $[12,98]$, with concentrations as high as $40 \mu \mathrm{g} / \mathrm{g}$ at the surface in Bangladesh [78]. Meharg and Rahman [98] reasoned that the presence of high concentrations of solid-phase arsenic in the surficial layers may at least in part be attributed to the irrigational return flow of groundwater. Edmunds et al. [3] reported that irrigated soils evidently have higher arsenic concentrations (in the order of tens of $\mathrm{mg} /$ $\mathrm{Kg}$ ) than the non-irrigated soils $(5-10 \mathrm{mg} / \mathrm{Kg})$. Extensive irrigational pumping was practiced on a large scale since the early 1970s in both Bangladesh and West Bengal parts of the basin $[82,110]$. The irrigational pumps bring out the anxoic groundwater of the aquifers in contact to the atmospheric oxygen, and the arsenic is subsequently sequestered to the oxidized ferric iron in the agricultural fields [111, 112]. Thus, in the extensive rice fields of Bengal basin the arsenic content of the soil zone can increase in the order of $1 \mathrm{Kg} / \mathrm{ha} /$ year (assuming the gross irrigational requirement for rice to be $1000 \mathrm{~mm} /$ year and the input concentration to be $100 \mu \mathrm{g} / \mathrm{l})$, and this arsenic can be subsequently re-circulated to the groundwater, particularly in the dry seasons via enhanced recharge, adding to the groundwater arsenic problem [39, 82]. Edmunds et al. [3] and Roberts et al. [113] reported that around 1000-1360 tonnes of arsenic is added to the soils per year in Bangladesh. The recharging waters from the irrigation return flow may be organic matter rich and anoxic in nature, thus driving the reduction of metal hydroxides at the near surface or in the deeper levels of the aquifer [26, 32]. However, Roberts et al. [113] stated that arsenic inputs to paddy fields are spatially heterogeneous and arsenic concentrations significantly decrease away from the water inlet due to the progressive formation and precipitation of arsenic-bearing Fe aggregates and sorption of arsenic to clays. This can give rise to highly variable spatial distribution of arsenic in the topsoil [114]. However, the arsenic inputs to soils are found to be independent of the length of the irrigation channel.

Different irrigation schemes would supposedly lead to different patterns of arsenic distribution. Hence, designing of the irrigational systems and practices can be crucial for mitigation of arsenic enrichment in the soils. Passage of irrigational water through 'designated treatment fields' or ponds prior to reaching the irrigational fields may effectively attenuate the arsenic accumulation in the fields [113].

Roberts et al. [115] stated that during monsoonal flooding, soils release a large amount of arsenic to the floodwaters and this accounts for about $13-62 \%$ of total arsenic added per year to the soils due to the irrigational practices in their study site in Bangladesh. This arsenic is subsequently removed laterally to the rivers as the floodwaters recede [115]. This mechanism efficiently attenuates the arsenic concentration in the seasonally flooded agricultural fields and reduces the risk of arsenic enrichment (annual input rates of arsenic due to irrigational activities and annual release rates to monsoonal floodwaters balance each other and result in a annual steady state of arsenic in soils, involving intense temporal fluctuations) as opposed to the non-flooded soils which release arsenic only by volatilization and downward leaching [115]. This mechanism is also spatially dominant as $21 \%$ of the total area in Bangladesh is annually flooded in the monsoons, with floodwaters exceeding $0.9 \mathrm{~m}$ height [115].

Thus, to conclude, the arsenic in the groundwater of the Bengal basin is thought to have its source up in the Himalayas and is brought down by the river systems to the sites of recent sedimentation where it is reworked by irrigation return flow.

\section{Mobilization and Transport}

Several hypotheses have been put forward in relation to the mobilization and transport of arsenic. None of these hypotheses seem to completely explain the phenomena on a basinal scale. Multiple processes may operate in an area depending on the biogeochemical conditions [37] (Fig. 4). Biswas et al. [116] stated that the arsenic release mechanisms are depth dependent and complex. Given here is a list of the most plausible and accepted hypotheses regarding the arsenic mobilization and transport.

\section{Liberation to Solution and Retention}

Biogeochemical Redox Transformation

Reduction of Metal Oxides and Hydroxides The most widely accepted hypothesis is the reductive dissolution of iron 
Fig. 4 Flowchart showing the probable factors and processes resulting to arsenic enrichment in the groundwater of the Bengal basin (modified from [33])

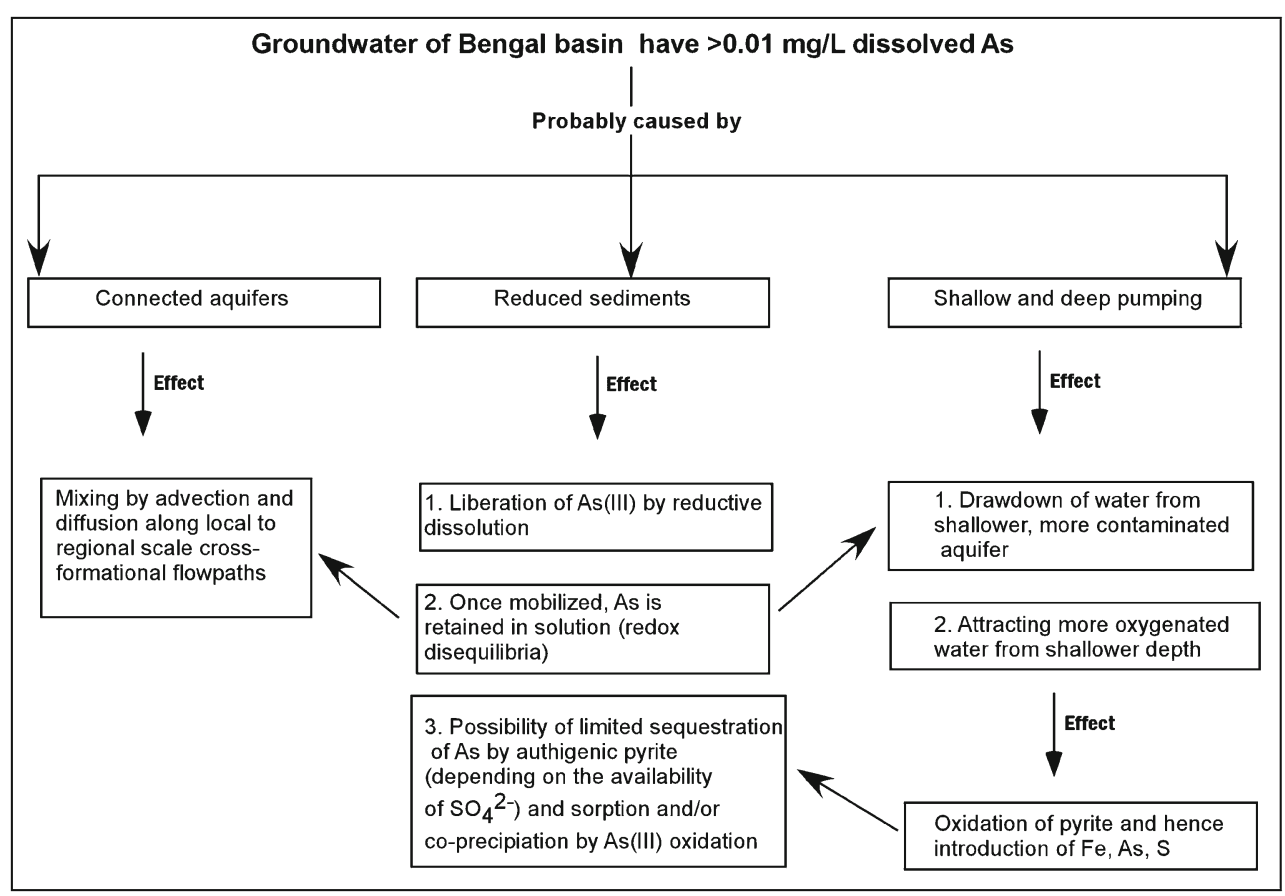

hydroxide, driven by microbially mediated degradation of organic carbon in the sediments releasing the sorbed arsenic into the groundwater $[4,6,12,13,25,26,28,32,36-38,55-57$, 80, 116-121]. This hypothesis was first proposed as the main mechanism of arsenic mobilization by Bhattacharya et al. [36]. The shallow aquifers of the Bengal basin are under a strong reducing condition, developed as a result of the surficial clay layers (wherever present) which restrict the inflow of oxygen into the aquifer, in addition to the consumption of dissolved oxygen for the oxidation of organic matter in the recently buried sediments [4, 13, 39]. Mukherjee and Fryar [37] reported that the Eh values, indicative of the redox conditions within the aquifers correspond to the $\mathrm{As}(\mathrm{V})$ and $\mathrm{Fe}(\mathrm{III})$ reduction process. Nickson et al. [57] stated the reaction that controls the reduction and the dissolution of the iron(III) hydroxide to $\mathrm{Fe}^{2+}$ with the generation of bicarbonate ions, along with the liberation of the entire sorbed load on iron hydroxides (which includes arsenic) into the groundwater.

$$
4 \mathrm{FeOOH}+\mathrm{CH}_{2} \mathrm{O}+7 \mathrm{H}_{2} \mathrm{CO}_{3} \rightarrow 4 \mathrm{Fe}^{2+}+8 \mathrm{HCO}^{3-}+6 \mathrm{H}_{2} \mathrm{O}
$$

This explains the correlation between arsenic and bicarbonate ions [28]. Ahmed et al. [6] reported that the degradation of the organic matter results in high concentrations of dissolved organic carbon in the groundwater. The authors further stated that the oxidative degradation of organic matter gives rise to high concentrations of bicarbonate, while the microbially mediated reductive fermentation produces biogenic methane. Several workers have reported methane in the aquifers from many parts of the basin $[38,122]$. The bicarbonate may also be supplied from local biogeochemical processes to the groundwater system [123, 124].

Several workers reported strong to moderate correlation between arsenic and iron which indicates the release of arsenic due to dissolution of and desorption from iron hydroxides in the sediments [117, 120]. Poor correlation between arsenic and iron has also been reported by many workers [12, 13, 28, 49, 57, 80, 123]. On a regional scale in West Bengal, Mukherjee and Fryar [37] reported a weak correlation between arsenic and iron hydroxide $\left(r^{2}=0.26\right)$, although $\mathrm{Fe}^{2+}$ and arsenite yielded a better correlation $\left(r^{2}=0.32\right)$. Harvey et al. [26] reported that the reducing nature of the groundwater and the weak but positive correlation of dissolved arsenic with iron and bicarbonate in the groundwater of their study site in Bangladesh indicate that the arsenic is either mobilized by reductive dissolution of iron hydroxides or reductive desorption of arsenate to arsenite. Chatterjee et al. [17] reported a moderate correlation in both total arsenic and bicarbonate and total iron and bicarbonate in the aquifers of West Bengal. The lack of correlation between iron and arsenic, as reported by several scientists, may apparently seem to limit the validity of the hypothesis (e.g. [27]). However, several workers have tried to explain the poor correlation of arsenic and iron in the aquifers. Islam et al. [125] reported that sorbed arsenic is released into the groundwater after the reduction of $\mathrm{Fe}(\mathrm{III})$ which results in the weak correlation between arsenic and iron. One of the hypotheses to explain such poor correlation between arsenic and iron states that microbially mediated reduction of iron oxyhydroxide is promoted by the bicarbonatebuffered groundwaters (as indicated by the partial pressure of carbon dioxide in the aquifers) and the low correlation between the total arsenic and total iron (and strong correlation 
of total iron with sulfate and phosphate, indicative of a reducing environment with high sulfate and phosphate concentrations) may arise due to the complexation of these bicarbonate ions with reduced $\mathrm{Fe}(\mathrm{II})$, which re-precipitates in the form of siderite or vivianite giving rise to the non-conservative behavior of $\mathrm{Fe}^{2+}$ in the groundwater and complicating the correlation of arsenic and iron [6, 17, 25, 57, 126-128]. Moreover, Zheng et al. [121] claimed that arsenic remains in dissolved state even under $\mathrm{SO}_{4}$ reducing conditions. McArthur et al. [55] argued that the lack of covariance between dissolved arsenic and iron in the groundwater does not question the validity of the iron reduction hypothesis for arsenic mobilization because of the following reasons: Firstly, iron and arsenic do not behave conservatively in solution and can be differentially sequestered into diagenetic pyrite; secondly, weathering of biotite adds substantial iron to the groundwater; thirdly, the proportion of arsenic present within the $\mathrm{FeOOH}$ is variable and thus gives a varied $\mathrm{Fe}^{2+} / \mathrm{As}$ ratio on dissolution; and finally, the dissolved iron can be taken up by mixed valence oxides and hydroxycarbonates. Zheng et al. [129] reported that, although the reduced aquifer sediments in Bangladesh with $\mathrm{Fe}(\mathrm{II}) / \mathrm{Fe}$ ratio $>0.5$ are likely to contain high arsenic concentrations [27], the grey sediments from the deeper parts of the Holocene aquifers in parts of Bangladesh are not arsenic enriched in spite of high $\mathrm{Fe}(\mathrm{II}) / \mathrm{Fe}$ ratio, probably because the sorption capacity of the aquifer sediments is enough to sequester the relatively low concentration of mobile arsenic from the groundwater. The lack of correlation between arsenic and other parameters (e.g. Fe, $\mathrm{Mn}, \mathrm{HCO}_{3}{ }^{-}, \mathrm{NH}_{4}{ }^{+}, \mathrm{CH}_{4}$ and $\mathrm{pH}$ ) indicates the contribution of the total mobilized arsenic from multiple complex processes [37].

McArthur et al. [28] stated that the high concentrations of arsenic in the groundwater of the Holocene aquifers can be attributed to the complete dissolution of $\mathrm{FeOOH}$ driven by the microbial metabolism of organic matter, releasing the entire sorbed load of arsenic and is indicated by the good correlation between the arsenic and the $\mathrm{HCO}_{3}{ }^{-}$ions in the groundwater of the Bengal basin aquifers. The authors further argued that the Himalaya-derived immature sediments supplied to the basin have suffered a very low degree of oxidative weathering along their transport and were subsequently deposited in waterlogged anoxic conditions resulting in a very low surface loading of $\mathrm{FeOOH}$, which in the presence of abundant organic matter undergoes complete reduction. The authors further reasoned that most of the finer grain sizes were transported further offshore, while the coarser sediment fraction with reduced surface area was left behind to host the FeOOH coatings. Harvey et al. [38] reported that purely ferric hydroxides which were hypothesized to sequester arsenic, are either very rare if not completely absent in the aquifers of Bangladesh. McArthur et al. [28] reported ferric hydroxide in the Pleistocene oxidized aquifers of Bangladesh and argued that the Pleistocene aquifers have undergone oxidative weathering, which has resulted in increased $\mathrm{FeOOH}$ concentrations than their Holocene counterparts. Nickson et al. [57] also attributed the low concentration of arsenic in the Pleistocene aquifers to the oxidation of the abundant $\mathrm{Fe}^{2+}$ ions and flocculation and filtration of the ironhydroxides, which sorbs arsenic from the groundwater. Polizzotto et al. [78] further added that the abundance of ferric hydroxides in these aquifers act as sorption sites for arsenic and thus prohibit the mobilization of arsenic at large.

Horneman et al. [27] reported that the release of arsenic by the process of reduction of iron hydroxide coatings on sands does not necessarily involve the dissolution of iron hydroxide, as it is predominantly linked to the transformation of $\mathrm{Fe}$ (III) hydroxide to $\mathrm{Fe}$ (II) or mixed $\mathrm{Fe}(\mathrm{II} / \mathrm{III})$ phases, while the iron is still retained as a solid phase. Horneman et al. [27] further claimed that this hypothesis can explain the observation that the dissolved iron concentrations are not consistent with the dissolved arsenic concentrations or the $\mathrm{Fe}(\mathrm{II}) / \mathrm{Fe}$ concentrations in sediments (also reported by [38]), while the distribution of dissolved arsenic seems to be related to the redox states of the leachable iron fraction in sediments. Van Geen et al. [49] however, suggested that microbial reduction of arsenic may not be required for mobilization once the sediment itself has been altered under reducing conditions [130, 131]. Van Geen et al. [49] further argued that microbial activities can mobilize arsenic to groundwater, even without extensive iron dissolution. It is thus interesting to note that the reduction and mobilization of $\mathrm{Fe}(\mathrm{III})$ and $\mathrm{As}(\mathrm{V})$ are found to be decoupled [49, 125, 132].

Chatterjee et al. [17] argued that the biogeochemically catalyzed $\mathrm{Fe}$ (II)-Fe(III) cycling within the aquifers may act as the principal process controlling arsenic mobilization. Chatterjee et al. [17] further reported that the cyclic behavior of iron in the Bengal basin may also be sustained by the presence of nitrate (acting as an electron donor) in the groundwater which is primarily supplied from anthropogenic sources. Mukherjee and Fryar [37] claimed that although mobilization of arsenic is dominantly caused by microbial reduction of (Fe(III)/Mn) hydroxides, Fe-S-C redox cycles control the mobilization of arsenic. Smedley and Kinniburgh [4] claimed that desorption and reductive dissolution of $\mathrm{Mn}$ oxides can also contribute to the arsenic concentrations in the groundwater as much as FeOOH. However, McArthur et al. [28] argued that reduction of Mn oxides precedes the reduction of Fe oxides and once the arsenic sorbed to Mn oxides is released it is subsequently resorbed to $\mathrm{FeOOH}$, rather than being released to the groundwater [120]. Ravenscroft et al. [39] claimed that detrital biotite may prove to be a potential source of arsenic to the groundwater of the Bengal basin. Breit et al. [107] reported the presence of arsenic in biotite in areas of Bangladesh. Ravenscroft et al. [39] further argued that although the iron hydroxide dissolution hypothesis is widely supported, the weathering of biotite may also substantially add up to the arsenic in the 
Bengal basin and the contribution from the two processes varies with depth.

McArthur et al. [55] claimed that reductive dissolution of ferric hydroxide would not be triggered if organic matter is not available to drive the microbial reduction in the aquifer sediments of Bangladesh. Covariance of elevated arsenic concentrations in groundwater with high content of metabolic byproducts, such as inorganic carbon, methane and ammonium, and $\mathrm{Fe}$ (II), indicates that the 'microbial metabolism of organic carbon' is the dominant 'master-process' $[8,55]$ in the reductive dissolution of iron hydroxide.

Reduction of $\mathbf{A s}(\mathbf{V})$ to $\mathbf{A s}($ III) The microbial degradation of organic matter not only promotes the reduction of $\mathrm{Fe}$ (III) to $\mathrm{Fe}(\mathrm{II})$ but also facilitates the reduction of $\mathrm{As}(\mathrm{V})$ to $\mathrm{As}(\mathrm{III})[6$, 119]. The microbially mediated reduction of the arsenate to arsenite is thought to mobilize arsenic into the groundwater under strongly reducing aquifer conditions persisting in the shallower aquifers of the Bengal Basin (e.g. [25, 125, 133-137]). As(V) is known to be adsorbed to sediments in a much greater extent than As(III). Harvey et al. [38] claimed that the reduction and subsequent mobilization of arsenic can be caused by the respiration of organic carbon, in spite of the paucity of Fe(III) oxyhydroxides. Van Geen et al. [49] argued that the reduction process occurring within the aquifer sediments concentrates the arsenic present in a comparatively labile phase, which under subsequent microbial reduction is mobilized into the groundwater without the need of substantial iron reduction. Routh and Hjelmquist [138] reported that, unexpectedly high concentrations (24-74\%) of $\mathrm{As}^{3+}$ species in the shallow aquifers of their study area in West Bengal are solely not the result of redox conditions in the aquifer but is at least partly contributed by microbial reduction of $\mathrm{As}^{5+}$. A wide range of aerobic and anaerobic microorganisms can metabolize $\mathrm{As}^{5+}[138-140]$ at a much faster rate than the redox processes $[141,142]$ and this microbially mediated arsenic cycling encompasses oxidation, reduction and methylation reactions $[49,138,140]$. Anoxic conditions promote the dissimilatory reduction of $\mathrm{As}^{5+}$, where the anaerobic microorganisms gain energy by the coupled oxidation of organic matter and reduction of $\mathrm{As}^{5+}$ which acts as a terminal electron acceptor for the microorganisms [133, 138, 140, 143]. However, van Geen et al. [49] argued that the mobilization of arsenic may not necessarily involve its microbial reduction once the sediments have suffered alterations under reducing conditions.

However, this hypothesis is limited by the observation that iron hydroxide can strongly sorb both arsenite and arsenate under a wide variety of redox conditions [129, 144, 145] and rather the reduction of iron hydroxide sorbent itself can prove to be the key process for mobilization of arsenic into the groundwater [129]. Moreover, it is difficult to differentiate the contribution of dissolved arsenic from the reduction of
Fe hydroxides from that of the reduction of solid phase arsenic [8].

Sources of Organic Matter and Biogeochemical Processes Van Geen et al. [49] argued that without the catalytic effect of the microbial activity, the abiotic reduction of iron hydroxide would have proceeded very slowly and the arsenic content of the groundwater of the Bengal basin would not have been enriched to this extent. The microbial metal reduction, however, may be limited by the presence of organic matter (electron donor) [125]. The decomposition of organic matter in the anoxic aquifers of the Bengal basin prevails under conditions where the biological oxygen demand is higher than the oxygen supply rates resulting in anaerobic metabolism of the organic matter involving microbially mediated reduction of $\mathrm{Fe}(\mathrm{III})$ accompanied by $\mathrm{As}(\mathrm{V})$ during the advanced stages of reduction $[8,33]$.

The organic carbon can be both autochthonous and allochtonous in nature [8]. The most plausible sources of organic carbon are: Peat layers within the aquifer-aquitard framework [28, 39, 55, 118], dispersed organic matter within the aquifer sediments $[36,146]$ or infiltration of natural or anthropogenic organic carbon from the bottom of the ponds or other surficial sources into the groundwater system [32, 147]. Nickson et al. [57] claimed the source of organic matter to be sedimentary. Yamazaki et al. [146] reported high content of arsenic $(121 \mathrm{mg} / \mathrm{Kg})$ in the NOM-rich fine-grained muddy sediments and low arsenic content $\left(0.7-23 \mathrm{mg} \mathrm{Kg}^{-1}\right)$ in the NOM-poor sediments in a village of Bangladesh. McArthur et al. [55] argued that the areal distribution of peat layers in the aquifer sand matrix and the overlying confining clay layers is the dominant control on the arsenic distribution in groundwater. However, Pal et al. [148] claimed that aquifers underlying peat layers yield arsenic-free water in their study area in West Bengal and thus questioned the role of peat layers in the regional scale arsenic pollution. McArthur et al. [28] explained that the presence of an impermeable layer below the peat layers may be a likely explanation for such an observation. On the other hand, peat seems to be scarce or absent in the older floodplain and delta areas with high arsenic concentrations in parts of West Bengal [37]. Moreover, Harvey et al. [38] reported no peat layers in their study area in Bangladesh and argued that the mobilization of arsenic is not related to detrital organic carbon. Harvey et al. [38] further argued that irrigation-pumping-induced inflow of the young inorganic carbon through rice fields and organic-rich ponds and river bottoms mobilizes the older organic carbon (probably by release from iron hydroxide grains which are known to sequester organic carbon), which in turn drives the biogeochemical processes mobilizing arsenic, involving organic carbon-driven reduction or displacement by bicarbonate. McArthur et al. [28] on the contrary, argued that the $\mathrm{CH}_{4}$ in the aquifers (reported by Ahmed et al. [122], Harvey et al. [38] 
and Pal and Mukherjee [85]) proves the presence of subsurface organic matter around the study areas and claimed that the surface sources of organic matter proposed by Harvey et al. [38] do not seem to be a likely redox driver controlling the fate of arsenic mobilization due to the following reasons: Firstly, if the surface sources of organic matter would have been the dominant source of carbon to the aquifers then neither would the arsenic enrichment be localized to only $25 \%$ of the wells in Bangladesh and nor would the arsenic contaminated wells be limited to only the Holocene aquifers, leaving out the Pleistocene-aged Madhupur and Barind tracts [55, 118]; secondly, nor would the arsenic concentrations be highest around $\sim 20-40 \mathrm{~m}$ deep groundwater of the Bengal basin $[29,38,55,118,149]$; and finally, the dissolved organic carbon (DOC) is highest around $30 \mathrm{~m}$ depth and remains moderately high upto $80 \mathrm{~m}$ depth, which indicates a deep source for the DOC.

An alternative source of organic matter was thought to be of anthropogenic origin and consists of dissolved NOM derived from the human wastes and agricultural activities, which infiltrates through the agricultural fields and surface water bodies $[9,26,32,38,146]$. The increased rate of pumping causes the rapid downflow of the NOM and the mobilized arsenic [9, 26, 32, 38]. Datta et al. [22] however, argued that the perennial ponds do not serve as an important source of organic matter to the aquifer system of their study area in West Bengal and the arsenic rich groundwater is primarily recharged from local precipitation without significant mixing with pond waters. Moreover, the time required for pondderived organic matter to reach the shallow aquifers would be thousands of years, much greater than the age of the shallow arsenic-rich groundwater ( $\sim 50$ years) and thus in situ organic matter seems to be a possible source driving the microbially mediated reductive dissolution of iron oxyhydroxides and subsequent mobilization of arsenic [150]. McArthur et al. [28] reported that dug latrines do not contribute to additional release of arsenic on a regional scale but can promote some mobilization very locally either by contaminating adjacent wells at an individual level or if they penetrate the upper confining layer of the aquifer system. Mukherjee et al. [151] argued that even though the surface sources of organic matter can be a geochemical factor for arsenic mobilization in the shallower aquifers owing to the large population and the land use patterns in the basin, it does not explain the arsenic enrichment in the groundwater of the deeper aquifers because the oxidation of NOM is constrained within the shallower depths under natural vertical hydraulic gradients. Chatterjee et al. [17] argued that the native use of cow dung (easily degraded and decomposed by microbial action) as a cementing material for tube well construction may also act as a local carbon source which leads to high arsenic concentrations in the recently installed tube wells. Lawson et al. [152] showed that both surficial organic matter and organic matter from sedimentary sources may contribute to the total DOC of the groundwater. Lawson et al. [152] further argued that the surface-derived DOC can infiltrate from the bottom of the ponds or wetlands or through discontinuities/ 'windows' in the surficial clay layers, while the sedimentary sources of organic carbon can be leached by recharging water infiltrating through a young ( $<6000$ years) organic-matter rich layer of sediments. It is however, important to note that some portion of the solid phase $\mathrm{As}(\mathrm{V})$ is associated with refractory iron oxyhroxides and is thus not bioavailable for reduction by microorganisms $[125,153]$. Pleistocene deeper aquifers contain low arsenic concentrations due to the recalcitrant/ refractory nature and limited availability of the organic matter present at that depth $[8,96,121]$.

Rowland et al. [153] reported the presence of petroleumrelated organic matter of terrigenous origin derived from a single source of deeper thermally matured rocks which undergoes biodegradation by indigenous microbial community in their study site in West Bengal.

Islam et al. [125] stated that the mobilization of arsenic from sediments of West Bengal is probably catalyzed by the anaerobic metal-reducing bacteria. Islam et al. [125] further reported that abundant Fe(III)-reducing bacteria in the sediments use the bioavailable Fe(III) ions as electron acceptors and subsequently reduce the reactive portion of the sedimentbounded $\mathrm{As}(\mathrm{V})$ for their respiration and release $\mathrm{As}(\mathrm{III})$ to the groundwaters. Cumming et al. [130] reported that the activity of the dissimilatory bacterial strains like Shewanella BrY mediates and enhances the reductive dissolution of iron hydroxides without reduction of arsenic. Dhar et al. [132] showed that metal reducers like Shewanella can substantially mobilize arsenic to groundwater by transforming sedimentary arsenic to mobilizable form, even in absence of abundant organic matter. Islam et al. [125] reported that anaerobic bacteria sequences closely related to Clostridium species, capable for organic matter degradation and metal (including As) reduction are found within the sediments. The dissimilatory microbial reduction of $\mathrm{As}(\mathrm{V})$ to $\mathrm{As}(\mathrm{III})$ may also be stimulated in the presence of suitable substrates, perhaps by the same class of microorganisms responsible for sulfate reduction $[49,145$, 154]. Islam et al. [125] also detected specialist metalreducing dissimilatory bacteria with some clones closely associated with Geobacter type sequences in $\delta$-Proteobacteria, which are known to be dominantly present in the zones of $\mathrm{Fe}(\mathrm{III})$ reduction and is capable of reducing a large number of metals, but not $\mathrm{As}(\mathrm{V})$.

\section{Inorganic Geochemical Processes}

Pyrite Oxidation Hypothesis The pyrite oxidation model hypothesizes the release of arsenic by oxidation of pyrite and/or arsenopyrite, probably due to the lowering of the water table as a result of large-scale groundwater pumping in the 
aquifers of West Bengal and parts of Bangladesh [92, 93, 155]. The lowering of the water table exposes the Holocene anoxic grey sediments to atmospheric oxygen which causes the oxidation of pyrite grains into soluble sulfate, thus releasing the arsenic load to the groundwater. Moreover, Mukherjee et al. [33] argued that enhanced groundwater recharge (under the action of the increased discharge) due to shallow and deep pumping causes increased inflow and deeper penetration of dissolved oxygen into the grey-reducing aquifer sediments. Mallick and Rajgopal [155] also reported the mixing of reduced and oxidized groundwater as a result of pumping.

However, the low concentrations of sulfate in the groundwater and the inverse correlation of arsenic with sulfate, coupled with the reducing conditions persisting in the aquifers limit the possibility that arsenic could be mobilized from sulfide minerals [6, 26, 32]. Harvey et al. [38] also reported an inverse correlation between arsenic and sulfate in the porewaters of the Holocene aquifers of Bangladesh. Moreover, the presence of the pyrite grains indicate that the aquifer is not oxidized enough to mobilize the arsenic from the pyrite and rather, the pyrite grains formed by biogenic mineralization $[17,90]$ act as arsenic sinks to sequester the dissolved arsenic from the groundwater [151]. McArthur et al. [55] argued that the pyrite oxidation hypothesis would not apply to the reducing grey aquifers of the Bengal basin because of the following reasons: Firstly, the arsenic even if released from pyrite oxidation would be re-adsorbed by the oxidized $\mathrm{FeOOH}$, rather than being released into the groundwater; secondly, the sulfate and the arsenic concentrations in the groundwater are mutually exclusive, which is inconsistent with the arsenic being released by pyrite oxidation; and thirdly, if the pyrite in the sediments would have mobilized arsenic under oxidizing conditions then water in the shallow dug wells would have been high in arsenic, which is contrary to the observations.

On the other hand, Chatterjee et al. [17] reported the presence of high arsenic and sulfate concentrations in the shallow private tube wells where the sulfate is supplied from adjacent pit latrines or from surface of a low lying area.

Competitive Ion Exchange Mechanism Once a pool of arsenic and other species are mobilized by the dissolution of its host minerals, the released ions compete between each other and the existing adsorbed species for saturation sites resulting in further release of weakly complexed species, like As(III) into the groundwater [8]. Ahmed et al. [6] reported that the concentrations of sulfate and nitrate are generally low in groundwater and arsenic in the system is not correlated with sulfate or nitrate. Silicates are also thought to be a potential competitor of arsenic for sorption sites $[4,26,32,116,138$, 156-158]. Chlorine recharging from wastewaters and pit latrines is also considered to be a potential species for the ion exchange [178]. Carbonates and bicarbonate are also known to displace arsenic from the sediments $[4,26,38,116,138$,
156, 157]. Appelo et al. [156] presented the surface complexation constants for carbonate and ferrous ions on ferrihydrite and modelled the phenomena of competitive ion exchange and surface complexation for arsenic. The model results conclude that the sorption of carbonate in natural soil and groundwater concentrations effectively reduces the sorption of arsenic on ferrihydrite. The authors further hypothesized that the arsenic-enriched sediments within the surface waters with low carbonate concentrations are eventually buried and thus come in contact with the carbonate-rich groundwater with the subsequent release of sorbed arsenic because of the competitive displacement of arsenic by the carbonates. The most significant chemical species involved in this ion exchange process is phosphate, probably derived from the fertilizers to a large extent [26, 63, 64, 116, 138, 157]. Although Ravenscroft et al. [118] reported that the spatial distribution of phosphate correlates well with arsenic, several other studies showed poor correlation between the two [90, 159]. Ravenscroft et al. [39] argued that phosphate presumably does not play a role in mobilizing arsenic, but seems to have a common origin. McArthur et al. [55] explained that the release of arsenic by competitive ion exchange of phosphorous supplied from the fertilizers does not seem to be logical enough, because had phosphorous been supplied by the fertilizers, the newly recharged groundwater with low bicarbonate concentration would have appreciable amount of phosphorous which is contrary to the following observations: Young waters with bicarbonate concentrations lower than $200 \mathrm{mg} / \mathrm{L}$ do not have significant amount of phosphorous or arsenic; in parts of Bangladesh, phosphorous concentrations increase with depth (based on BGS/DPHE [13]) and groundwater with high phosphorous concentrations may also be high in arsenic. Moreover, many scientists reported the absence of phosphate fertilizers in areas of high arsenic groundwater and vice versa $[55,118]$. Hence, McArthur et al. [55] concluded that fertilizer phosphate does not contribute to the arsenic pollution. However, the authors agreed that authigenic phosphate (with phosphorous sourced from latrines and buried peat layers) can mobilize arsenic to some degree but its effect is negligible at the regional scale. However, phosphate is presumed to be the most potential competitor for ion exchange with arsenic, while silica imposes a weaker control on such exchange processes and the bicarbonate ions have a negligible effect in mobilizing arsenic [28, 157].

Reduction and Oxidation Hypothesis Zheng et al. [121] proposed an integrated hypothesis to explain the mobilization of arsenic which was later taken up by Mukherjee et al. [174] This hypothesis stresses on the reduction of iron hydroxide as the key process in the mobilization of arsenic along with some local oxidation of pyrite grains by the dissolved oxygen from the recharging waters adding to the effect. Ferric 
hydroxide and sulfide cycling within the aquifers controls the mobilization and re-sequestration of arsenic from the groundwater under the effect of partial redox equilibria [15]. Polizzotto et al. [95] on the other hand, argued that the dissimilatory reduction of ferric hydroxide does not seem to be the most dominant electron-accepting process under the given redox conditions persisting in the aquifers. Moreover, the iron hydroxides in the Holocene aquifers have undergone complete reduction in the past to release its entire sorbed load of arsenic [28] and thus, most of the Holocene aquifers are depleted of ferric hydroxides [28, 95]. Hence, Polizzotto et al. $[78,95]$ argued that arsenic is released into the aquifers from the near-surface sediments due to the effect of the seasonal cycles of redox condition caused by the seasonal rise and fall of the water table, involving oxidation of pyrite followed by inflow of carbon-rich surface waters which reduce the ferric hydroxide and liberate arsenic from the aquifers, which is subsequently transported to the deeper levels (Fig. 5). The authors argued that the seasonal water table rise and fall as a result of the monsoons and extensive groundwater abstraction during the dry seasons control the passage of oxygen into the aquifers, which in turn influences the seasonal redox cycles of the near surface sediments [78]. During the oxic cycles, the surficial sulfide mineral grains release arsenic which are adsorbed to or co-precipitated with the ferric hydroxides, which in turn undergo reductive dissolution during the subsequent period of recharge (e.g. monsoonal and flooding events, irrigational return flow) releasing arsenic to the groundwater, which is then transported to the aquifer depths [78]. During the reducing cycle, only a small amount of authigenic sulfide re-sequesters some arsenic because most of the sulfur has already been removed and transported in the form of dissolved sulfate during the oxic cycles and moreover, the re-sequestration of arsenic is limited by the competition from the other ions, e.g. $\mathrm{Fe}^{2+}$ for the adsorption sites [78]. The authors reasoned that the continuous influx of arsenic-enriched surficial sediments and the cyclical changes in redox conditions trigger the continuous release of arsenic (which is essential to keep up the elevated arsenic concentrations in the aquifer, specially under the high flushing rates as a result of irrigational pumping in the recent times) mostly in the form of arsenite, which, due to its low distribution coefficient is weakly sorbed to the sediments on its flow path and is transported to well depths. Moreover, the bell-shaped vertical profile of arsenic indicates a plume migration from the surficial depths $[26,32$, 78].

However, Stute et al. [47] argued that such a scenario would result in an inverse relationship between arsenic concentration and groundwater age as an effect of dispersive transport along the flow path which is contrary to the finding that the concentration of dissolved arsenic is directly correlated to groundwater age.
Thus, as Mukherjee et al. [9] concluded, the mobilization of arsenic in reduced aquifers of the Bengal basin is largely controlled by the reduction processes, but all mechanisms pertaining to the local oxidations, sorption of arsenic to the digenetic mineral phases, its desorption, re-sequestrations and co-precipitation under partial redox equilibria contribute to the fate of arsenic in the aquifers of the Bengal basin.

\section{Sink}

The arsenic once mobilized can be re-sequestrated to the solid phase under conducive redox conditions and the in presence of appropriate mineralogical sinks.

The pyrite mineral grains act as a major mineralogical sink and arsenic mobilized from the aquifers can be re-sequestered to pyrites under reducing conditions in the grey sediments of the Bengal basin [37, 39, 55]. Lowers et al. [89] claimed that most of the Bangladesh groundwater are saturated with pyrite and arsenopyrite at circum-neutral $\mathrm{pH}$. Abundant authigenic framboidal and massive pyrites act as principal arsenic sinks (median As values: 1500 and $3200 \mathrm{mg} / \mathrm{Kg}$, respectively) yielding low arsenic groundwater in the aquifers of the Bengal basin [89]. Arsenic can either adsorb to pyrite forming an arsenopyrite-like surface precipitate [160] or can substitute sulfur within the lattice spaces [161]. However, Lowers et al. [89] argued that most of the arsenic are introduced into the pyrite during its formation, although substitution of arsenic for sulfur may also play a role. Mukherjee and Fryar [37] argued that $\delta^{34} \mathrm{SO}_{4}$ results indicate that $\mathrm{SO}_{4}{ }^{2-}$ reduction takes place within the aquifers resulting in the deposition of authigenic sulfide minerals (mainly pyrite), which partially sequesters the dissolved arsenic [89] from the groundwater and the sorption of arsenic to sulfide minerals are mostly constrained by the partial redox equilibria and limited supply of sulfate in deeper groundwater. Mukherjee et al. [25] argued that the aquifers of the Bengal basin comprise of overlapping redox zones resulting in partial redox equilibria where arsenic once mobilized from the sediments would tend to remain in solution. Zheng et al. [121] claimed that arsenic continues to be in the dissolved state under $\mathrm{SO}_{4}$-reducing conditions indicating that authignic pyrite does not serve as a potential arsenic sink of significant importance. In areas where the reduction of $\mathrm{FeOOH}$ is incomplete, the residual $\mathrm{FeOOH}$ in the sediments may resorb some dissolved arsenic upto its sorption saturation keeping the arsenic concentrations of the groundwater low $[28,118]$. Significant oxidation capacity is found in the deeper grey Holocene sediments [27, 38, 157].

Burgess et al. [96] argued that deep grey Pleistocene aquifers progressively bound arsenic to authigenic pyrite (and arsenian pyrite, to a lesser extent) as a result of diagenetic alterations forming a sink of refractory arsenic in these reducing aquifers. In the Pleistocene oxidized aquifers, ferric 
Fig. 5 A conceptual model showing seasonally controlled oxidation of As bearing sulfides accompanied by the formation of ferric oxides (which adsorb the liberated arsenic), followed by its reductive dissolution and release of arsenic into the groundwater (modified from [78])

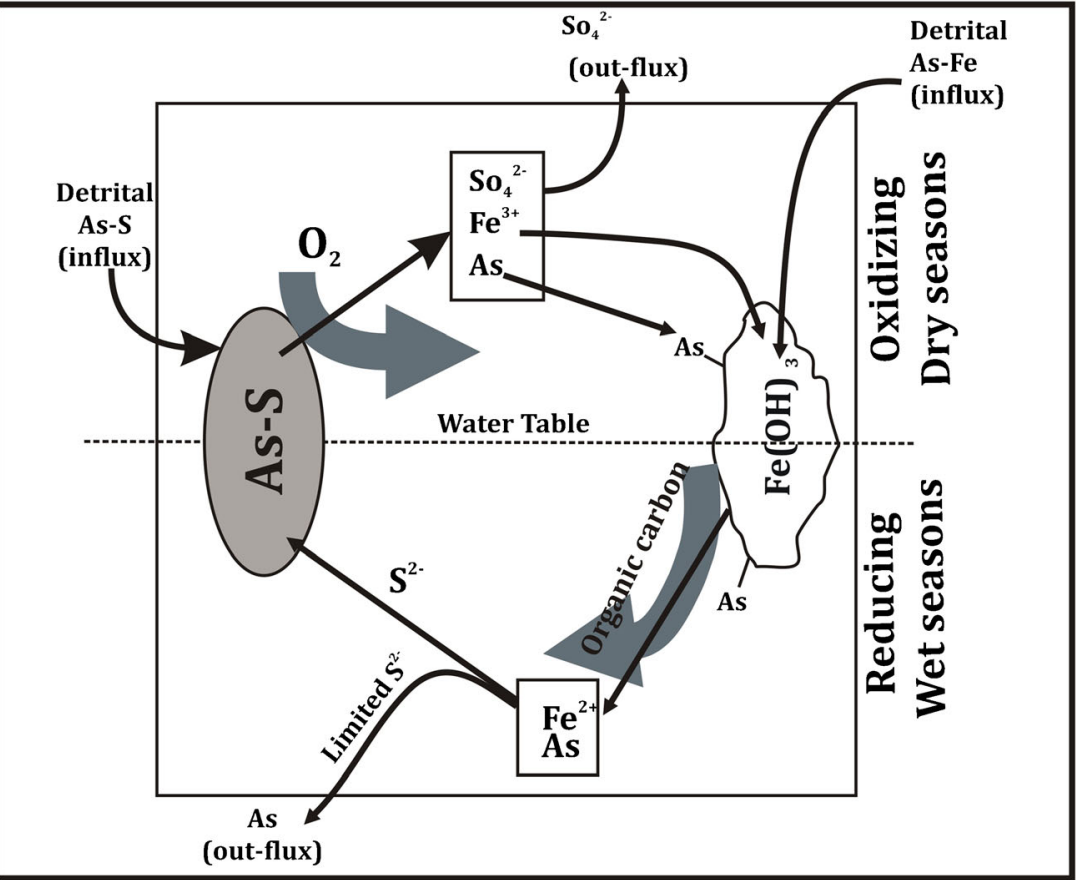

hydroxides adsorb the arsenic from the groundwater, keeping the arsenic concentrations in these aquifers mostly within permissible limits [78]. The higher content of $\mathrm{FeOOH}$ in the sediments of these aquifers [28] acts as sorptive buffer, inhibiting extensive arsenic mobilization in the aquifer. The removal of arsenic from groundwater in oxidized sediments may also be driven by oxidation of $\mathrm{As}(\mathrm{III})$ to $\mathrm{As}(\mathrm{V})$ by manganese minerals and subsequent adsorption of $\mathrm{As}(\mathrm{V})$ [157, $162,163]$. The coupled oxidation of arsenic and reduction of manganese oxide is highly favoured in presence of microbes, though the reaction may also proceed abiotically $[157,164]$. Stollenwerk et al. [157] further concluded that the deeper oxidized sediments have considerable adsorption capacity for arsenic, which is limited by the availability of oxidant (like $\mathrm{Mn})$ in the Bengal basin.

\section{Factors Controlling Arsenic Distribution in Groundwater}

The distribution patterns of arsenic in the Bengal basin depend on the geology and geomorphology, hydrological and anthropogenic factors, such as local sedimentation patterns, groundwater flow, availability of organic carbon, effects of pumping, application of fertilizers, etc. [8, 96].

\section{Geologic and Geomorphologic Controls}

The geology (as well as the physiographic divisions) of the Bengal basin plays a role in the arsenic distribution within the Bengal aquifer system [39]. Ahmed et al. [6] classified the aquifer system in the eastern part of the basin into the shallower aquifers (above $200 \mathrm{~m}$ ) and the deeper aquifers (below $200 \mathrm{~m}$ ) separated by a thick yet discontinuous layer of clay aquitard. To the western part of the basin, a thick basal clay aquitard is overlain by a single semi-confined continuous sand aquifer which breaks up into multiple aquifer units seperated by clay aquitards towards the southern end [82].

The delta plains of the Ganges-Bramhaputra-Meghna river system, the recent floodplains and the Syllhet trough are highly enriched in arsenic [165]. The delta plains to the south of the basin are the worst affected areas, while the northern and central floodplains are moderately contaminated $[6,26]$. Thirty five percent of the 1747 sampled wells in the Ganges floodplains have arsenic concentrations over $50 \mu \mathrm{g} / \mathrm{L}$, whereas in the Brahmaputra (and Tista) floodplains it is $25 \%$ of 524 wells and is $53 \%$ of 810 wells in the Meghna floodplains of Bangladesh [39]. This correlates well with the dominance of medium to coarse grained sediments in large parts of the Brahmaputra and Tista floodplains, while the Meghna river system is dominated by finer clastics, thus indicating that lithology and grain size control the arsenic content of the aquifers in the basin [39]. Weinman et al. [166] however, pointed out that concentration of groundwater arsenic not only varies with grain size, but is also controlled by the thickness and the spatial distribution of the fine-grained sediment caps overlying the aquifer sands. The 'older gravelly sand' unit and the 'young gravelly sand' unit of the Tista fan in north-western Bangladesh consist of recent coarse-grained sediments with low content of iron oxide and lack a thick confining silt or clay unit and thus, yield very low arsenic concentrations, where the older gravelly sand unit yields even lower concentrations of arsenic than the younger 
sand unit [11]. The fine-grained sediments deposited at the lower reaches of the Bengal basin are rich in mud and organic matter (especially in the overbank sediments) and thus are enriched in colloidal hydroxides containing sorbed arsenic [39]. The surficial layers of silt and clay cap the aquifers below and restrict the inflow of oxygen into the aquifers, which in combination with the presence of recent solid organic matter result in the development of extensive reducing conditions within the aquifer system [4, 13, 39]. Moreover, the spatial heterogeneity of the shallow sediments resulting from the complex depositional pattern during the Holocene times controlled by the interaction of the high-energy rivers and the flood and delta plains has led to the development of small scale variability in arsenic concentrations [31]. Zones of arsenic enrichments are found within localized potential microenvironments, like paleochannels and abundant meanders giving rise to arsenic plumes and are correspondingly manifested as patchy zones of arsenic contamination at the surface $[29,85,86]$. Such environments contain elevated arsenic due to the presence of abundant labile organic carbon and arsenic-bearing iron oxides, as a result of seasonal flooding along with infiltration of DOC-rich recharge and slow groundwater flow. On the other hand, the older Tertiary and Quaternary sediments and the Pleistocene Barind and Madhupur Clays show consistently low concentrations of arsenic with very few wells yielding groundwater with arsenic concentrations greater than $50 \mu \mathrm{g} / \mathrm{L}$ [11]. Weinman et al. [166] developed an understanding of the influence of local river history and sedimentation patterns (developed not only due to the fluvio-deltaic action but also anthropogenic activities, e.g. artificial filling for flood protection) on the redox states of the aquifers and physico-chemical processes controlling the reaction and transport of shallow groundwater arsenic and its spatial distribution. The authors noted that shallow high-arsenic groundwater occurs mainly in areas underlying (or proximal to) thick deposits of surficial silt or clay, whereas areas with low arsenic are characterized by surficial exposures of aquifer sands. Such a disparity can be attributed to the fact that coarser grained sands occur at higher elevations (owing to their deposition under the high flow regimes in the braided channel systems, including levees and bars) which not only causes rapid oxic recharge and enhances the flushing rates due to the development of higher hydraulic heads, but also limits the inflow of arsenic enriched groundwater from the fine-grained low-lying areas due to the potentiometric barrier [166]. On the other hand, the finer grained clays and silts are essentially found in lowlying areas (owing to their deposition under low-energy flow regimes in the floodplains and the meandering levees and bars) with longer groundwater residence time and dominant reducing environments due to reduced hydraulic conductivity and finer grain size [166]. It is also interesting to note that the artificial fillings constructed for flood protection may act as a mimic to the thick fine-grained caps overlying the aquifer sands causing high arsenic concentrations in the shallow groundwater [166].

The Holocene grey shallow aquifers are the most contaminated aquifers of the Bengal basin and $30.5 \%$ (and upto $\sim 77 \%$ ) of the shallow wells in Bangladesh within these recent alluvial and deltaic sediments have arsenic concentrations higher than $50 \mu \mathrm{g} / \mathrm{L}[11,39]$. Pleistocene deeper aquifers contain low arsenic concentrations due to the oxidized nature of the sediments (which leads to the sequestration of arsenic to the ferric oxyhydroxides), the history of enhanced groundwater flushing and the refractory nature of the organic matter [96]. To add to this, Bromssen et al. [80] explained that the oxidized sediments are low in arsenic either because of the abundant undersaturated adsorption sites for arsenic within these sediments, in the absence of reductive dissolution of iron oxyhydroxide, or because the reducible fraction of arsenic in these sediments is low. Pal and Mukherjee [85] argued that the orange sands in the Pleistocene sediments act like 'natural filters' for arsenic, although all Pleistocene aquifers are not arsenic free. Burgess et al. [96] claimed that the area around the Pleistocene inliers and the Tertiary Hills contains oxidized sediments with very high adsorption capacity as a result of sustained oxidizing environment due to continuous oxic recharge, as opposed to the isolated oxidized sand lenses which are expected to have lower adsorption capacities owing to their exposure to reduced groundwater, at least to some extent. Burgess et al. [96] further argued that the deep grey Pleistocene sediments bound arsenic to pyrites which act as arsenic sinks under reducing environments.

During the Late Quaternary eustatic lows, the basin experienced reduced rainfall and a lower water table height complemented by rapid recharge and development of circumneutral oxic environment promoting oxidative weathering and re-crystallization of amorphous oxyhydroxides along with high rates of aquifer flushing resulting in the removal of organic matter and thus, the Pleistocene aquifers of the Bengal basin have experienced flushing and immobilization of any arsenic present in the groundwater [39]. Subsequently, the sea level started to rise rapidly and at about $11 \mathrm{Ka}$ the basin experienced the development of a broad shallow shelf with increased river discharge, higher rainfall and higher temperatures, resulting in the development of mangrove swamps and fresh peat basins [39]. Such development of waterlogged anoxic conditions coupled with low hydraulic gradients, resulted in negligible aquifer flushing or fresh oxic recharge and promoted strongly reducing environments in the presence of abundant organic matter and peat. These factors facilitated the mobilization and detainment of arsenic in the Holocene aquifers of the Bengal basin. This period of rapid sea level rise around 10,000 to 5500 years BP coincides with highest arsenic contamination confined within the arseniferous middle unit of the Bengal aquifer system $[11,35]$. 
Shamsudduha et al. [165] reported that most of the arsenic-affected tube wells in the Bengal basin are located in areas with low topography (mean surface elevation of nearly $10 \mathrm{~m}$ ), gentle slopes $\left(<0.7^{\circ}\right)$ and low groundwater elevation (mean: $4.5 \mathrm{~m}$, above the Public Works Datum (PWD)), all of which are controlled by geomorphology, geology, precipitation and abstraction within the basin (Fig. 6). The lower topography and the gentle slopes of the flood and delta plains result in the accumulation of finer clastics along with arsenic-adsorbed iron oxyhydroxides and organic matter [117, 165], which when coupled with the reducing conditions release arsenic by microbially mediated reductive dissolution of iron hydroxide [125] and the arsenic keeps on accumulating owing to the slow aquifer flushing. Thus, Shamsudduha et al. [165] concluded that the spatial distribution of arsenic in low-lying areas of the Bengal basin is mostly controlled by the regional topography and the slow groundwater flushing rates.

McArthur et al. [167] described the effect of subsurface geology and presence of paleosols on the arsenic distribution of the aquifers and reads "palaeo-channel sequences dissecting a buried, palaeosol-capped, Pleistocene landscape, all covered by a rapidly deposited and laterally extensive Holocene interfluvial sequence, that may be muddy or sandy". Ravenscroft et al. [39] reported that aquifers older than the Last Glacial Maximum (LGM) do not show severe arsenic contamination on a large scale. McArthur et al. [167] demonstrated that the presence of the Last Glacial Maximum Palaeosol (LGMP), overlying the brown Pleistocene sands in the paleo-interfluvial sequence protects the underlying Pleistocene aquifers from the downward flow of groundwater carrying organic matter and the dissolved arsenic. On the other hand, in the absence of the LGMP, as in the paleo-channel sequences, there is a hydraulic connectivity between the Pleistocene and the Holocene sands, which promotes the downward migration of organic matter and dissolved arsenic from the above lying Holocene aquifer resulting in arsenic contamination within the Pleistocene sands [167]. The authors further stated that the arsenic-contaminated groundwater from the paleo-channel sediments flows laterally into the palaeo-interfluvial sands (with the arsenic moving at the rate of 0.2 to $1 \mathrm{~m} /$ day) where the arsenic is sorbed to the sediments, thus minimizing the arsenic contamination. Thus, McArthur et al. [167] argued that the arsenic migration do not occur by a diffused, laterally extensive, downward leakage of arsenic-enriched groundwater and rather the vertical flows between the aquifers are constricted within zones of high permeability that are separated by dominant horizontal flow paths. To conclude, the authors argued that further modeling and monitoring would be needed to understand the likely period of sustainability of the paleo-interfluvial aquifers in delivering low arsenic groundwater.

\section{Hydrological and Hydrogeological controls}

Under natural conditions, flow stratification caused by the presence of multiple discontinuous aquitards inhibits the mixing of shallow and deep groundwater in most parts of the basin, excepting areas with thick palaeo-channel sands promoting focused vertical flows of arsenic-rich shallow groundwater to the deeper aquifers, as in the west-central Bangladesh where greater than $10 \%$ deep wells (deeper than $200 \mathrm{~m})$ are arsenic contaminated [96]. Harvey et al. [26, 32] reported the dissolved arsenic concentrations to peak at the depth zone of the mixing of younger and older groundwater.

Van Geen et al. [127] argued that the difference in arsenic concentrations between the shallow and the deep aquifer systems within the basin may be an effect of the difference in flushing histories of these aquifers for the last thousands of years. The effect of lowering of the arsenic content in the aquifer sediments and groundwater due to increased flushing within the aquifers $[28,47]$ is juxtaposed by the effect of increasing content of arsenic owing to either enhanced arsenic input from surficial sources or enhanced inflow of organic carbon (Fig. 7) by simple mixing of older and younger groundwater as a result of increased groundwater pumping [38, 168, 169]. Van Geen et al. [127] demonstrated the effect of the advection velocity, dispersion coefficient (D) and retardation factor $(\mathrm{R})$ of arsenic on its flushing time from the aquifer and stated that the effect of change in groundwater velocity on arsenic concentration is inversely proportional to that of the change in flushing time, for the given $\mathrm{D}$ and $\mathrm{R}$ for arsenic. The model results by Van Geen et al. [127] suggested that the shallow aquifers would take about 500 years to be depleted of arsenic and by 5000 years it would almost be completely free of arsenic. Desbarats et al. [46] claimed that, given the present rate of arsenic depletion, a kilogram of arsenic bearing sediments (containing $7.3 \mathrm{mg} / \mathrm{Kg}$ of As, on an average) would take 521a to be depleted of its arsenic. Polizzotto et al. [95] stated some possible explanations as to why there are such high concentrations of groundwater arsenic in the Bengal basin, inspite of the high flushing rates compared to the age of the basin: Firstly, the high rate of flushing in the recent times is an effect of extensive irrigation and had not been so in the past centuries; secondly, the biogeochemical conditions have evolved to be conducive for arsenic mobilization to a greater extent in the present times; thirdly, a continuous supply of organic carbon or dissolved arsenic is provided from an upgradient source by near surface to surficial processes. Harvey et al. [38] reported that in their study site in Bangladesh, the arsenic has been recently mobilized as indicated by the radiocarbon dating of the dissolved inorganic carbon.

Datta et al. [150] noted very high concentrations of arsenic (upto $23,000 \mathrm{mg} / \mathrm{Kg}$ ) within the shallow subsurface sediments from the banks of the Meghna river and attributed such elevated concentrations to adsorption of dissolved arsenic to the 

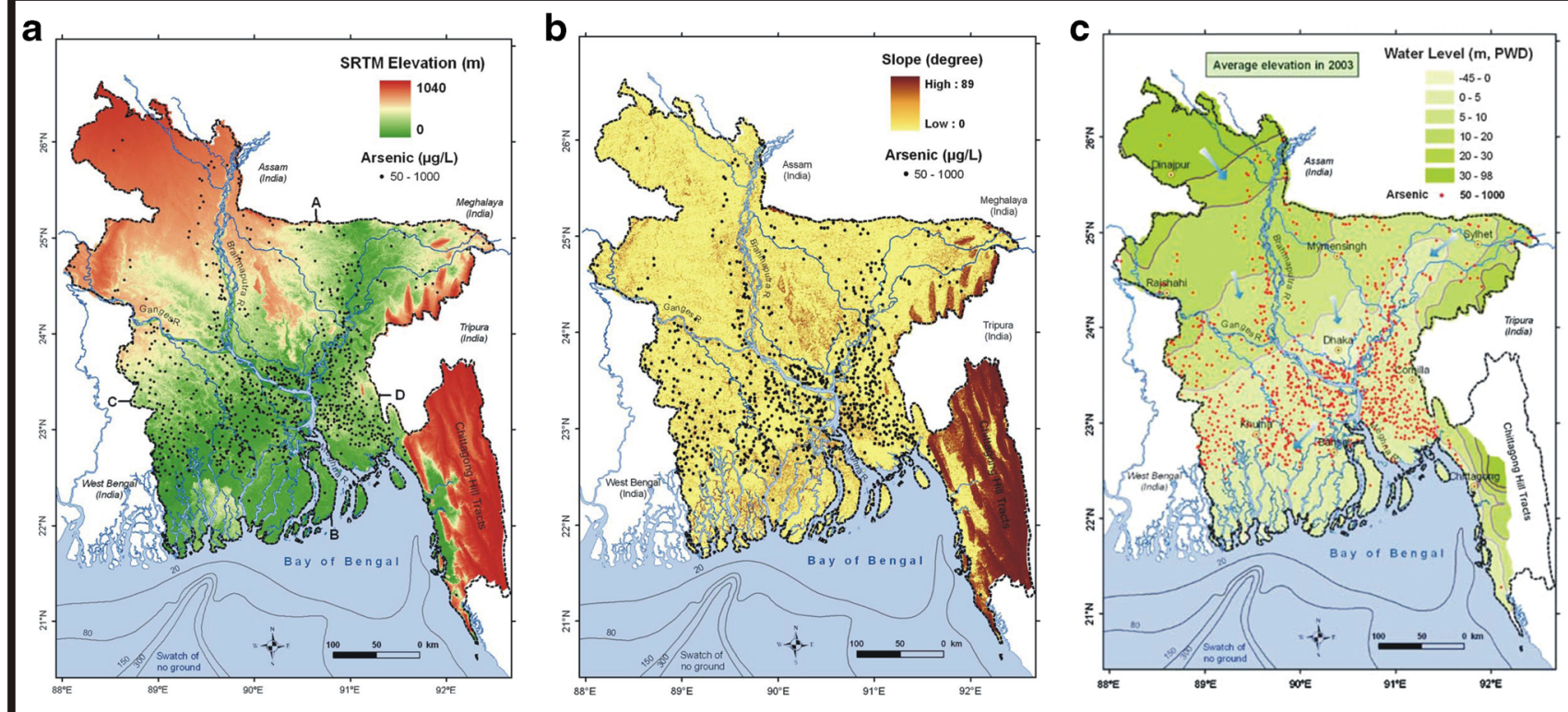

Fig. 6 Maps showing the effect of geomorphic and hydrogeologic factors on groundwater arsenic in the Bangladesh part of the basin: a) topography, b) slopes and c) groundwater elevation (modified from [165])

natural reactive barrier, formed by the secondary iron-bearing minerals at the discharge points along the river, due to the redox transition and oxidation of such mineral species during the dry season. The reactive barrier is formed just above the capillary fringe, where arsenic-rich ferric oxides are formed by bacterial oxidation and co-precipitation of Fe(II) and $\mathrm{As}$ (III) in connection to the oxic river water [150]. Thus, Datta et al. [150] argued that a portion of the arsenic is retained within the aquifers in the discharge zones as the groundwater flushes out and such accumulations of arsenic in the sediments remain as potential sources of arsenic in the aquifers, which may subsequently be remobilized to the groundwater during the flow reversals from the rivers or river banks to the aquifers, either during dry seasons or as an effect of irrigational pumping. In an alternative scenario, the arsenic-rich sediments can suffer burial under the action of the modern prograding delta and give rise to arsenic hotspots or may be eroded and redeposited by the Ganges-Bramhaputra-Meghna river system and subsequently remain within the aquifers as dispersed particulates of potential arsenic source [150].

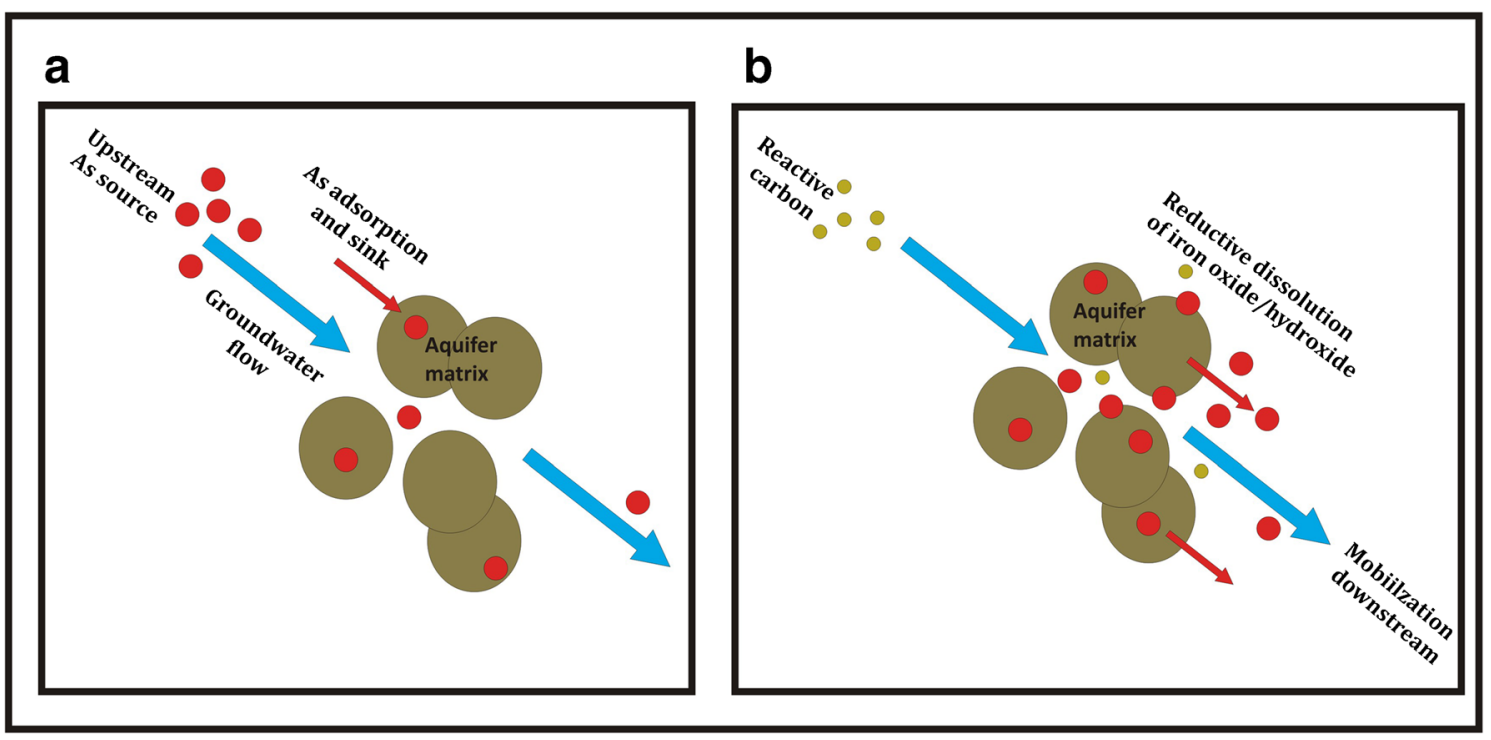

Fig. 7 A conceptual representation of the a) ex-situ and b) in-situ arsenic sources, where groundwater may either directly transport arsenic or can act as a carrier of organic matter, which is known to trigger the reductive dissolution of iron hydroxide, mobilizing arsenic (modified from [34]) 
Such accumulation of arsenic for 10,000 years can account for as much of arsenic as the total arsenic in the shallow aquifer sediments [150].

\section{Anthropological Intervention/Pumping}

Das et al. [92] and Mallick and Rajgopal [155] argued that extensive pumping lowers the groundwater table exposing the pyrite in the surficial sediments to oxidation and thus liberates arsenic. Several workers noted such lowering of the water table [91, 170] in connection to the increased irrigational pumping around the 1970s [151]. This was indeed followed by the first detection of arsenic contamination in West Bengal during 1978 and an increase in the number of reported cases of arsenicosis. However, such hypothesis cannot be tested because of the lack of detailed study around that time [39].

Mukherjee et al. [82] argued that the enhanced recharge as a result of extensive pumping generates downward fluxes of water enriched in dissolved oxygen [171] and organic carbon [38] which perturb the redoxdependent biogeochemical reactions in the aquifer system (Fig. 8). Lawson et al. [152] showed that intensive groundwater pumping has led to enhanced infiltration of DOC from the surficial sources (e.g. pond bottoms) to great depths, which would not have taken place under natural hydraulic gradients.

However, arsenic concentrations in irrigation wells are found to be lower than that of the monitoring wells [169, 172] and it is presumed to be the effect of the constant rate arsenic release from the aquifers coupled with increased water flux due to enhanced irrigational recharge and groundwater flushing [47]. Ravenscroft et al. [39] carried out a statistical test to spatially correlate the elevated arsenic concentrations in groundwater with two parameters: 'the maximum recorded depth to the water table over the period 1961-93' and 'the percentage of the area of each upazila irrigated by groundwater in 1996', reflecting the extent of groundwater pumping. Both the parameters were found to be negatively correlated to arsenic contamination and hence, Ravenscroft et al. [39] argued that irrigational pumping is necessarily not the primary cause of arsenic contamination in the groundwater.

The model results of Cuthbert et al. [173] demonstrated that vertical leakage in a hand pumped tube well (HTW) would cause an increase in arsenic concentration in the tube well water with time, if the tube well screen is below the arsenic source depth. Cuthbert et al. [173] further showed that if a HTW is situated within the catchment area of a deeper and more productive irrigation or water supply tube well, arsenic would reach the HTW more rapidly (Fig. 8) and the seasonal variations of arsenic concentration in the HTW would be controlled by the seasonal variations in the discharge of the irrigation tube well. However, these factors must be taken as secondary influences on the arsenic concentration of a tube well [39]. Mukherjee et al. [82] studied the effect of pumping on deeper groundwater and argued that extensive pumping coupled with the absence of confining units to the north and central parts of the basin has caused pumping induced mixing between the shallower and the deeper aquifers in their study area in West Bengal, leading to arsenic enrichment in the deeper aquifers [174]. Burgess et al. [96] claimed that widespread domestic extraction of groundwater from deep handpumped tube wells may inhibit arsenic invasion for hundreds of years. Burgess et al. [96] further argued that shallow irrigational pumping provides an additional hindrance against the downward arsenic flux by creating a hydraulic barrier between the two groundwater flows regime, while in contrast large-scale deep irrigational pumping can cause substantial contamination of arsenic in the arsenic-free deeper parts of the aquifers within decades. Radloff et al. [175] claimed that the sorption of the arsenic carried by the shallow infiltrating waters to the deep aquifers significantly retards the arsenic transport in the deeper groundwater and thereby reduces the extent of arsenic contamination, especially when the aquifers are exploited only for the domestic use. Radloff et al. [175] further added that high capacity deep irrigation wells can cause downward migration of arsenic-enriched reducing waters into the deeper oxidized aquifers causing arsenic contamination, and longer flow paths sourcing from high arsenic areas or shorter flow paths within the shallow basinal areas, connecting the arsenic enriched shallow aquifers to the deeper zones are potential areas of concern, while tube wells placed below a great sediment thickness or a clay capping are considered to be safer. Desbarats et al. [46] reported that wells tapping flow paths traversed through thick channel fill deposits consistently show high arsenic concentrations. Chatterjee et al. [17], on the other hand, argued that the arsenic enrichment in the deeper aquifers indicates that the Pleistocene sediments, which were once oxidized and arsenic free [4] have undergone subsequent reduction, at least in some parts of the aquifers. Michael and Voss [176] also stated that installations of deep irrigation wells on a large scale can contaminate the deeper low arsenic groundwater, by inducing rapid downward flow of arsenic rich water from the shallower aquifer. On the other hand, the presence of confining layers towards the southern part of the basin obstruct the advective-dispersive mixing of the shallow, arsenic enriched groundwater with the deeper groundwater along natural and pumping-induced vertical and horizontal flow paths [33].

Nitrates, sulfates, phosphates and organic matters are released into the aquifers from human wastes (sewage) beneath the areas of dense population $[28,39,168,177,178]$ and also from the use of fertilizers [63]. Van Geen et al. [168] reported an inverse relationship between the faecal contamination and the 
a

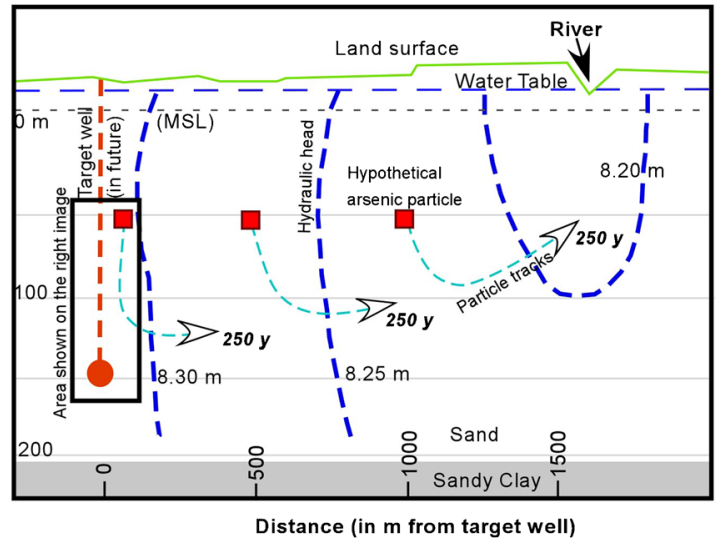

b

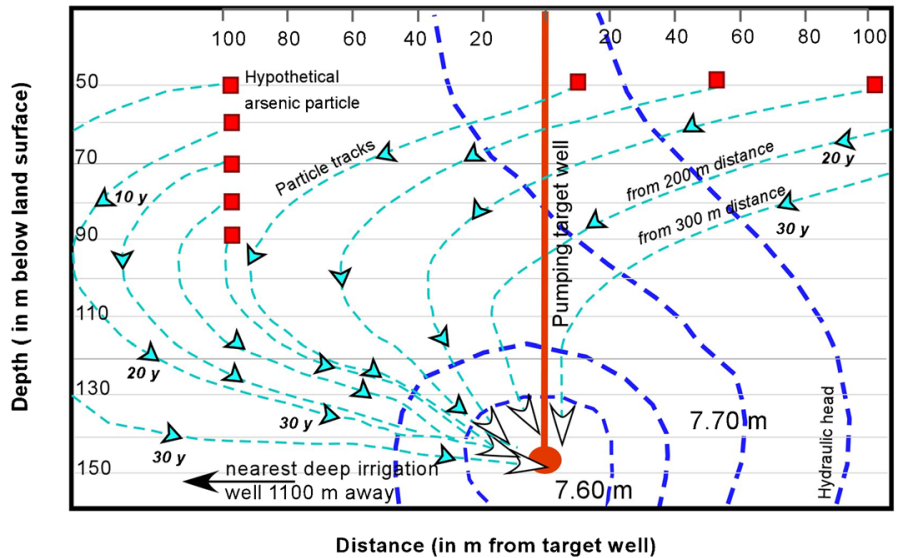

Fig. 8 A particle-tracking model showing the time of travel of a hypothetical arsenic particle from a given point to the well depths a) under natural hydraulic gradients and $\mathbf{b}$ ) under the influence of present-day irrigational and water-supply pumping. The dashed green lines represent the particle flow paths. The elapsed time between two green arrowheads

groundwater arsenic in the aquifers of Bangladesh. McArthur et al. [28] argued that dug latrines may contaminate adjacent wells or penetrate the aquifer in absence of a confining clay layer, but these do not contribute to the contamination at a regional scale. Van Geen et al. [168] further reported that 'conditions conducive to faecal contamination such as low As concentrations (i.e., a sandy setting) or the lack of a protective platform obscure the impact of population density without markedly increasing the level of faecal contamination'. McArthur et al. [178] reported that wastewaters from the septic tanks and pit latrines lower the arsenic pollution due to the activity of nitrate and sulfate in regions proximal to the source, while it enhances the arsenic pollution due to the presence of organic matter and chlorine, in areas far from the source, where the effect of the nitrates and sulfates has exhausted. The nitrate oxidizes the Fe(II) to ferric hydroxides [177], causing the sequestration of arsenic from the groundwaters. On the other hand, the phosphate causes mobilization of arsenic by competitive displacement of arsenic from the ferric hydroxides [63].

Mukherjee et al. [82] concluded that owing to aquifer architecture of the basin, the land use patterns have caused regional aquifer system to be more vulnerable to arsenic enrichment.

\section{Conclusion}

High concentration of arsenic has been proved to be toxic to human health. The extent and severity of the arsenic pollution in the groundwater of Bengal basin have named it 'the largest mass pollution in human history'. The large scale shift from surface water to groundwater usage in order to avoid surfacewaterborne diseases, has exposed about 35 and 15 million people to arsenic concentrations exceeding $50 \mu \mathrm{g} / \mathrm{L}$ in the along a single flow-line (in scenario b) is 10 years. The model results show an abrupt decrease in the travel time of the arsenic particles in the irrigational and pumping scenario, as opposed to 'under natural hydraulic gradients' (modified from [33])

drinking waters of Bangladesh and West Bengal, respectively. The groundwater arsenic concentrations within the Bengal basin are found to be as high as $4600 \mu \mathrm{g} / \mathrm{L}$. About 12 districts in Bangladesh and 5 districts in West Bengal are under severe arsenic contamination. The arsenic in the basin is known to have a nonpoint geogenic origin, although contribution from anthropogenic sources can add to the problem. The arsenic is derived from an upgradient source, located primarily in the Himalayas and the surrounding provinces drained by the Ganges-Bramhputra-Meghna river system. The aquifer matrix serves as the immediate source of arsenic, which under conducive environment releases arsenic to the groundwater. Ferric hydroxides and pyrites are considered to be the two most important host minerals for arsenic, although clay minerals can also account for a substantial amount of sorbed arsenic. Another potential source of arsenic is the 'irrigation return flow' from the agricultural fields. All these sources release arsenic to the groundwater under conducive environment. Microbially mediated reductive dissolution of ferric hydroxides mobilizing arsenic is the most accepted hypothesis relating to the release of arsenic to the groundwater. Other mechanisms like pyrite oxidation, redox cycling in surficial soils and competitive ion exchange are also accepted as potential mechanisms for arsenic mobilization, and multiple processes may contribute to the total mobilized arsenic. The mobilization of arsenic is intricately related to the geomorphology, geology, hydrogeology, groundwater flow paths and anthropogenic causes. The potential environment to produce the extent of groundwater arsenic as in the Bengal basin is a typical combination of biogeochemical and hydrologic environments where the aquifer conditions are conducive for arsenic mobilization and the effective flushing is very slow, as not to 
flush out much arsenic. However, none of the hypotheses completely explain the fate of arsenic within the basin and such hypotheses are applicable mostly at a local scale. The geological complexities of the basinal architecture, the unpredictable nature of the anthropogenic influences and the variable dynamics of such natural systems hinder the applicability of one unifying hypothesis to the whole of the basin. Thus, it is important to understand the applicability of each hypothesis in relation to the different parts of the basin.

Acknowledgements We are grateful to the reviewers for their constructive views and suggestions which have immensely improved the quality of this manuscript. The authors also acknowledge Soumendra Bhanja, Prerona Das, Swati Verma, and Palash Debnath, Pramod Rokade and Srimanti Duttagupta for their continuous support and contribution is the process of paper writing. The authors also thank Dr. Jayanto Routh and Dr. Rupali Dutta for their editorial help.

\section{References}

1. Alam M, Alam MM, Curray JR, Chowdhury MLR, Gani MR. An overview of the sedimentary geology of the Bengal basin in relation to the regional tectonic framework and basinfill history. Sediment Geol. 2003;155:179-208.

2. Mukherjee A, Fryar AE, Thomas WA. Geologic, geomorphic and hydrologic framework and evolution of the Bengal basin, India and Bangladesh. J Asian Earth Sci. 2009;34:227-44.

3. Edmunds WM, Ahmed KM, Whitehead PG. A review of arsenic and its impact in groundwater of the Ganges-BramhaputraMeghna delta, Bangladesh. Environ Sci Proc Impact. 2015. doi: 10.1039/c4em00673a.

4. Smedley PL, Kinniburgh DG. A review of the source, behaviour and distribution of arsenic in natural waters. Appl Geochem. 2002;17(5):517-68.

5. Coleman JM. Deltas: processes of deposition and models of exploration. 2nd ed. Minneapolis: Burgess; 1981

6. Ahmed KM, Bhattacharya P, Hasan MA, Akhter SH, Alam SMM, Bhuyian $\mathrm{MAH}$, et al. Arsenic enrichment in groundwater of the alluvial aquifers in Bangladesh: an overview. Appl Geochem. 2004;19:181-200.

7. Uddin A, Lundberg N. Cenozoic history of the Himalayan-Bengal system: sand composition in the Bengal Basin, Bangladesh. Geol Soc Am Bull. 1998;110:497-511.

8. Fendrof S, Micheal HA, van Geen A. Spatial and temporal variations of groundwater arsenic in South and Southeast Asia. Science. 2010;328:1123-7.

9. Mukherjee A, Fryar AE, O'Shea BM. Major occurrences of elevated arsenic in groundwater and other natural waters. In: Henke KR, editor. Arsenic-environmental chemistry, health threats and waste treatment. Chichester: Wiley; 2009. p. 303-50.

10. Guha Mazumder DN, Haque R, Ghosh N, et al. Arsenic levels in drinking water and the prevalence of skin lesions in West Bengal, India. Int J Epidemiol. 1998;27(5):871-7.

11. Kinniburgh DG, Smedley PL, Davies J, Milne CJ, Gaus I, Trafford $\mathrm{JM}$, et al. The scale and causes of the groundwater arsenic problem in Bangladesh. In: Welch, Alan H, Stollenwerk, Kenneth G, editors. Arsenic in groundwater. Boston: Kluwer Academic Publishers; 2003. p. 211-57.

12. Swartz CH, Koen Blute N, Badruzzaman B, Ali A, Brabander D, Jay J, et al. Mobility of arsenic in a Bangladesh aquifer: inferences from geochemical profiles, leaching data, and mineralogical characterization. Geochim Cosmochim Acta. 2004;68(22):4539-57.

13. BGS/DPHE (British Geological Survey/Department of Public Health Engineering [Bangladesh]). Arsenic contamination of groundwater in Bangladesh. In: Kinniburgh DG, Smedley PL, editors. Report WC/00/19, Keyworth: British Geological Survey Technical; 2001.

14. Gaus I, Kinniburgh DG, Talbot JC, Webster R. Geostatistical analysis of arsenic concentration in groundwater in Bangladesh using disjunctive kriging. Environ Geol. 2003;44(8):939-48.

15. Mukherjee AB, Bhattacharya P, Jacks G, Banerjee DM, Ramanathan AL, Mahanta C, et al. Groundwater arsenic contamination in India: extent and severity. Managing arsenic in the environment: from soil to human health. 2006. p. 553-93.

16. Smith AH, Lingas EO, Rahman M. Contamination of drinkingwater by arsenic in Bangladesh: a public health emergency. Bull World Health Organ. 2000;78(9):1093-103.

17. Chatterjee D, Halder D, Majumder S, Biswas A, Nath B, Bhattacharya $\mathrm{P}$, et al. Assessment of arsenic exposure from groundwater and rice in Bengal Delta Region, West Bengal, India. Water Res. 2010;44:5803-12.

18. Kapaj S, Peterson H, Liber K, Bhattacharya P. Human health effects from chronic arsenic poisoning - a review. J Environ Sci Health Part A Toxic/Hazard Subs Environ Eng. 2006;41:2399 428.

19. Garai R, Chakraborty AK, Dey SB, Saha KC. Chronic arsenic poisoning from tube-well water. J Indian Med Assoc. 1984;82(1):34-5.

20. Smedley P. Arsenic occurrence in groundwater in South and East Asia: scale, causes and mitigation. Towards a more effective operational response: arsenic contamination of groundwater in South and East Asian Countries II. Technical Report, World Bank Report No. 31303. Washington, DC: World Bank; 2005.

21. CGWB (Central Ground Water Board [India]). High incidence of arsenic in groundwater in West Bengal, Central Ground Water Board, Ministry of Water Resources, Government of India, Faridabad; 1999.

22. Datta S, Neal AW, Mohajerin TJ, Ocheltree T, Rosenheim BE, White CD, et al. Perennial ponds are not an important source of water or dissolved organic matter to groundwaters with high arsenic concentrations in West Bengal, India. Geophys Res Lett. 2011;38:L20404, doi:10.1029/2011 g1049301.

23. Ghosh AR, Mukherjee A. Arsenic contamination of groundwater and human health impacts in Burdwan District, West Bengal, India. Abstracts with programs. Geol Soc Am. 2002;34(2):107.

24. Rahman MM, Sengupta MK, Chowdhury UK. Arsenic contamination incidents around the world. In: Naidu R, Smith E, Owens $\mathrm{G}$, et al., editors. Managing arsenic in the environment: from soil to human health. Collingwood: CSIRO Publishing; 2006. p. 3-30.

25. Mukherjee A, von Brömssen M, Scanlon BR, Bhattacharya P, Fryar AE, Hasan MA, et al. Hydrogeochemical comparison and effects of overlapping redox zones on groundwater arsenic near the western (Bhagirathi sub-basin, India) and eastern (Meghna sub-basin, Bangladesh) of the Bengal basin. J Contam Hydrol. 2008a;99:31-48.

26. Harvey CF, Swartz CH, Badruzzaman ABM, et al. Groundwater arsenic contamination on the Ganges delta: biogeochemistry, hydrology, human perturbations, and human suffering on a large scale. Comp Rendus Geosci. 2005;337(1-2):285-96.

27. Horneman A, van Geen A, Kent DV, Mathe PE, Zheng Y, Dhar RK, et al. Decoupling of As and Fe release to Bangladesh groundwater under reducing conditions: part I. Evidence from sediment profiles. Geochim Cosmochim Acta. 2004;68:3459-73.

28. McArthur JM, Banerjee DM, Hudson-Edwards KA, Mishra R, Purohit R, Ravenscroft P, et al. Natural organic matter in 
sedimentary basins and its relation arsenic in anoxic ground water: the example of West Bengal and its worldwide implications. Appl Geochem. 2004;19:1255-93.

29. van Geen A, Zheng Y, Versteeg R, Stute M, Horneman A, Dhar R, et al. Spatial variability of arsenic in 6000 tube wells in a $25 \mathrm{~km} 2$ area of Bangladesh. Water Resour Res. 2003;39(5):1140. doi:10. 1029/2002WR001617.

30. van Geen A, Aziz Z, Horneman A, Weinman B, Dhar RK, Zheng $\mathrm{Y}$, et al. Preliminary evidence of a link between surface soil properties and the arsenic content of shallow groundwater in Bangladesh. J Geochem Explor. 2006;88(1-3):157-61.

31. Weinman B, Goodbred S, Zheng Y, et al. Fluvio-deltaic processes and geomorphic development at the scale of 100 to $1000 \mathrm{M}$ : their importance in governing the heterogeneity of groundwater arsenic in Araihazar, Bangladesh. Abstracts with programs. Geol Soc Am. 2006;38(7):180.

32. Harvey CF, Ashfaque KN, Yu W, et al. Groundwater dynamics and arsenic contamination in Bangladesh. Chem Geol. 2006;228(1-3):112-36.

33. Mukherjee A, Fryar AE, Scanlon BR, Bhattacharya P, Bhattacharya A. Elevated arsenic in deeper groundwater of the western Bengal basin, India: extent and controls from regional to local scale. Appl Geochem. 2011;26(4):600-13.

34. van Geen A. International Drilling to Recover Aquifer Sands (IDRAs) and arsenic contaminated groundwater in Asia. Scientific Drill. 2011;12:49-52. doi:10.2204/iodp.sd.12.06.2011.

35. Anawar HM, Akai J, Komaki K, Terao H, Yoshioka T, Ishizuka T, et al. Geochemical occurrence of arsenic in groundwater of Bangladesh: sources and mobilization processes. J Geochem Exp. 2003;77:109-31

36. Bhattacharya P, Chatterjee D, Jacks G. Occurrence of arsenic contaminated groundwater in alluvial aquifers from delta plains, eastern India: options for safe drinking water supply. Int J Water Resour Dev. 1997;13:79-92.

37. Mukherjee A, Fryar AE. Deeper groundwater chemistry and geochemical modeling of the arsenic affected western Bengal basin, West Bengal, India. ApplGeochem. 2008;23:863-94.

38. Harvey CF, Swartz CH, Badruzzman ABM, Keon-Blute N, Yu W, Ali MA, et al. Arsenic mobility and groundwater extraction in Bangladesh. Science. 2002;298(5598):1602-6.

39. Ravenscroft P, Burgess WG, Ahmed KM, et al. Arsenic in groundwater of the Bengal Basin, Bangladesh: distribution, field relations, and hydrogeological setting. Hydrogeol J. 2005;13(5-6): $727-51$.

40. Dhar RK, Zheng Y, Stute M, van Geen A, Cheng Z, Shanewaz M, et al. Temporal variability of groundwater chemistry in shallow and deep aquifers of Araihazar, Bangladesh. J Contam Hydrol. 2008;99:97-111. doi:10.1016/j.jconhyd.2008.03.007.

41. Ravenscroft P, McArthur JM, Hoque MA. Stable groundwater quality in deep aquifers of Southern Bangladesh: the case against sustainable abstraction. Sci Total Environ. 2013;454-455:627-38.

42. Burgess WG, Burren M, Perrin J, Ahmed KM. Constraints on sustainable development of arsenic-bearing aquifers in Southern Bangladesh. Part 1: a conceptual model of arsenic in the aquifer, in sustainable groundwater development. In: Hiscock KM, Rivett MO, Davidson RM, editors. Geol Soc London Spec Publ. 2000;193:145-16.

43. Burgess WG, Ahmed KM, Cobbing J, Cuthbert M, Mather S, McCarthy E, et al. Anticipating changes in arsenic concentration at tubewells in alluvial aquifers of the Bengal Basin, paper presented at Natural arsenic in sedimentary aquifers, XXXII IAH Congress on Groundwater and Human Development. Mar del Plata, Argentina: Int. Assoc. for Hydrogeol; 2002.

44. Cheng Z, van Geen A, Seddique AA, Ahmed KM. Limited temporal variability of arsenic concentrations in 20 wells monitored for 3 years in Araihazar, Bangladesh. Environ Sci Technol. 2005;39:4759-66.

45. Tareq SM, Safiullah S, Anawar HM, Rahman MM, Ishizuka T. Arsenic pollution in groundwater: a self-organizing complex geochemical process in the deltaic sedimentary environment, Bangladesh. Sci Total Environ. 2003;313:213-26.

46. Desbarats AJ, Koenig CEM, Pal T, Mukherjee PK, Beckie RD. Groundwater flow dynamics and arsenic source characterization in an aquifer system of West Bengal, India. Water Resour Res. 2014;50:4974-5002. doi:10.1002/2013WR014034.

47. Stute M, et al. Hydrological control of As concentrations in Bangladesh groundwater. Water Resour Res. 2007;43:W09417. doi:10.1029/2005WR004499.

48. Mandal BK, Chowdhury TR, Samanta G, et al. Arsenic in groundwater in seven districts of West Bengal, India the biggest arsenic calamity in the world. Curr Sci. 1996;70:976-86.

49. van Geen A, Rose J, Thoral S, Garnier JM, Zheng Y, Bottero JY. Decoupling of As and Fe release to Bangladesh groundwater under reducing conditions. Part II: evidence from sediment incubations. Geochim Cosmochim Acta. 2004;68:3475-86.

50. Bhattacharya P, Frisbie SH, Smith E, Naidu R, Jacks G, Sarkar B. Arsenic in the environment: a global perspective. In: Sarkar B, editor. Handbook of heavy metals in the environment. New York: Marcell Dekker Inc; 2002. p. 145-215.

51. Mukherjee A, Verma S, Gupta S, Henke KR, Bhattacharya P. Influence of tectonics, sedimentation and aqueous flow cycles on the origin of global groundwater arsenic: paradigms from three continents. J Hydrol. 2014;518:284-99.

52. Nordstrom DK. Worldwide occurrences of arsenic in ground water. Science. 2002;296:2143-5.

53. Mandal BK, Suzuki KT. Arsenic round the world: a review. Talanta. 2002;58:201-35.

54. Hossain MF. Arsenic contamination in Bangladesh - an overview. Agric Ecosyst Environ. 2006;113:1-16.

55. McArthur JM, Ravenscroft P, Safiullah S, Thirlwall MF. Arsenic in groundwater: testing pollution mechanisms for sedimentary aquifers in Bangladesh. Water Resour Res. 2001;37(1):109-17.

56. Nickson R, McArthur J, Burgess W, Ahmed KM, Ravenscroft P, Rahman M. Arsenic poisoning of Bangladesh groundwater. Nature. 1998;395:338.

57. Nickson RT, McArthur JM, Ravenscroft P, et al. Mechanism of arsenic release to groundwater, Bangladesh and West Bengal. Appl Geochem. 2000;15(4):403-13.

58. Ravenscroft P, Brammer H, Richards KS. Arsenic pollution: a global synthesis. Chichester: Wiley-Blackwell; 2009. doi:10. 1002/9781444308785

59. Mukherjee A, Bhattacharya P, Savage K, Foster A, Bundschuh J. Distribution of geogenic arsenic in hydrologic systems: controls and challenges. J Contam Hydrol. 2008;99:1-7.

60. Najman Y, Bickle M, BouDagher-Fadel M, Carter A, Garzanti E, Paul M, et al. The paleogene record of Himalayan erosion: Bengal Basin, Bangladesh. Earth Planet Sci Lett. 2008;273:1-14.

61. Qayyum M, Niem AR, Lawrence RD. Detrital modes and provenance of the paleogene khojak formation in Pakistan: implications for early Himalayan orogeny and unroofing. Geol Soc Amer Bull. 2001;113:320-32.

62. Ghosh S, De S. Sources of arseniferous sediments at Kachua and Itina, Habra Block, North-24 Paraganas, West Bengal. A case study. Indian J Earth Sci. 1995;22:183-9.

63. Acharyya SK, Chakraborty P, Lahiri S, Raymahashay BC, Guha $\mathrm{S}$, Bhowmik A. Arsenic poisoning in the Ganges delta. Nature. 1999;401(6753):545-7.

64. Acharyya SK, Lahiri S, Raymahashay BC, Bhowmik A. Arsenic toxicity of groundwater in parts of the Bengal basin in India and Bangladesh: the role of quaternary stratigraphy and Holocene sealevel fluctuation. Environ Geol. 2000;39(10):1127-37. 
65. Bhattacharya P, Jacks G, Gustafsson JP, Sracek A, Olofsson B, Aaltonen J, et al. High-arsenic groundwater in the alluvial aquifers of Bengal Delta Plains in Bangladesh: genesis and low-cost remediation. In Proceedings of KTH/Dhaka University Seminar on Groundwater Arsenic Contamination in the Bengal Delta Plains of Bangladesh, University of Dhaka, Dhaka, Bangladesh; 1999. 6-9.

66. BGS/MML [British Geological Survey/Mott MacDonald Ltd]. Groundwater studies for arsenic contamination in Bangladesh, Final report. Prepared for: Dept of Public Health Engineering, Govt of Bangladesh, Dhaka; 1999.

67. Ray AK. Chemistry of arsenic and arsenic minerals relevant to contamination of groundwater and soil from subterranean source. Everyman Sci. 1999;34:15-21.

68. Saha AK. Genesis of arsenic in groundwater in parts of West Bengal. Center for Studies on man and environment, Calcutta, Annual Volume; 1991.

69. Najman Y. The detrital record of orogenesis: a review of approaches and techniques used in the Himalayan sedimentary basins. Earth-Sci Rev. 2006;74:1-72.

70. Guilliot S, Charlet L. Bengal arsenic, an archive of Himalaya orogeny and paleohydrology. J Environ Sci Health Part A. 2007;42:1785-94.

71. Saunders JA, Lee MK, Mohammad S. Natural arsenic contamination of Holocene alluvial aquifers by linked tectonic, weathering, and microbial processes. Geochem Geophys Geosyst. 2005;6(4): Q04006. doi:10.1029/2004GC000803.

72. Stanger G. A palaeo-hydrogeological model for arsenic contamination in southern and south-east Asia. Environ Geochem Health. 2005;27:359-67.

73. Li S, Wang M, Y, Q, Wang H, Zhu J, Zheng B, et al. Enrichment of arsenic in surface water, stream sediments and soils of Tibet. $\mathrm{J}$ Geochem Exp. 2013. doi:10.1016/j.gexplo.2012.08.020.

74. Yin X, Liu X, Sun L, et al. A 1500-year record of lead, copper, arsenic, cadmium, zinc level in Antarctic seal hairs and sediments. Sci Total Environ. 2006;371(1-3):252-7.

75. Singh AK. Arsenic contamination in groundwater of North Eastern India. In: Jain CK, Trivedi RC, Sharma KD, editors. Hydrology with focal theme on water quality. New Delhi: Allied Publishers; 2004. p. 255-62.

76. Mok WM, Wai CM. Mobilization of As in contaminated river waters. In: Nriagu JO, editor. Arsenic in the environment, part 1, cycling and characterisation. New York: Wiley; 1994. p. 99-117.

77. Thornton I. Sources and pathways of As in the geochemical environment: health implications. In: Appleton JD, Fuge R, McCall GJH, editors. Environmental geochemistry and health 113. Geol. Soc. Spec. Publ.; 1996. p. 153-61.

78. Polizzotto ML, Harvey CF, Li G, Badruzzman B, Ali A, Newville $\mathrm{M}$, et al. Solid-phases and desorption processes of arsenic within Bangladesh sediments. Chem Geol. 2006;228:97-111.

79. Datta DK, Subramanian V. Texture and mineralogy of sediments from the Ganges-Brahmaputra-Meghna river system in the Bengal basin, Bangladesh and their environmental implications. Environ Geol. 1997;30:181-8.

80. Bromssen MV, Jakariya M, Bhattacharya P, Ahmed KM, Hasan MA, Sracek O, et al. Targeting low-arsenic aquifers in Matlab Upazila, Southeastern Bangladesh. Sci Total Environ. 2007;379: 121-32.

81. Ravenscroft P. Distribution of groundwater arsenic in Bangladesh related to geology. In: Jacks G, Bhattacharya P, Khan AA, editors. Groundwater arsenic contamination in the Bengal Delta Plain of Bangladesh. Proceedings of the KTH-Dhaka University seminar, University of Dhaka, Bangladesh. 2001 KTH Special publication, TRITA-AMI Report 3084, p. 41-56.

82. Mukherjee A, Fryar AE, Howell P. Regional hydrostratigraphy and groundwater flow modeling of the arsenic contaminated aquifers of the western Bengal basin, West Bengal, India. Hydrogeol J. 2007;15:1397-418.

83. Ahmed KM, Imam MB, Akhter SH, Hasan MA, Khan AA. Sedimentology and mineralogy of arsenic contaminated aquifers in the Bengal Delta of Bangladesh. In: Jacks G, Bhattacharya P, Khan AA, editors. Groundwater arsenic contamination in the Bengal Delta Plain of Bangladesh. Proc. KTH-Dhaka University Seminar, KTH Special Publication, TRITA-AMI Report 3084; 2001. p. $97-108$.

84. Breit GN, Foster AL, Perkins RB, Yount JC, King T, Welch $\mathrm{AH}$, et al. As-rich ferric oxyhydroxide enrichments in the shallow subsurface of Bangladesh. In: Wanty RB, Seal II, editors. Water-rock interactions. London: Taylor \& Francis Group; 2004. p. 1457-61.

85. Pal T, Mukherjee PK. Study of subsurface geology in locating arsenic-free groundwater in Bengal delta, West Bengal, India. Environ Geol. 2009;56:1211-25.

86. Charlet L, Chakraborty S, Appelo CAJ, Roman-Ross G, Nath B, Ansari AA, et al. Chemodynamics of an arsenic "hotspot" in a West Bengal aquifer: a field and reactive transport modeling study. Appl Geochem. 2007;22:1273-92.

87. Davis JA, Kent DB. Surface complexation modeling in aqueous geochemistry. Rev Mineral Geochem. 1990;23:177-260.

88. Benjamin MM, Leckie JO. Multiple-site adsorption of $\mathrm{Cd}, \mathrm{Cu}, \mathrm{Zn}$ and $\mathrm{Pb}$ on amorphous iron oxyhydroxide. J Colloid Interface Sci. 1981;79:209-21.

89. Lowers HA, Breit NG, Foster AL, Whitney J, Yount J, Uddin MN, et al. Arsenic incorporation into authigenic pyrite, Bengal Basin sediment, Bangladesh. Geochim Cosmochim Acta. 2007;71: 2699-717.

90. AAN/RGAG/NIPSOM (Asia Arsenic Network [AAN], Research Group of Applied Geology [RGAG], and National Institute for Preventive and Social Medicine [NIPSOM]). Arsenic Contamination in Groundwater in Bangladesh: interim report of the research at Samta Village, Asia Arsenic Network (AAN), Research Group of Applied Geology (RGAG), and National Institute for Preventive and Social Medicine (NIPSOM); 1999.

91. Chakraborti D, Basu GK, Biswas BK. Characterization of arsenicbearing sediments in the Gangetic delta of West Bengal, India. In: Chappell WR, Abernathy CO, Calderon RL, editors. Arsenic exposure and health effects IV. Oxford: Elsevier Science; 2001.

92. Das D, Samanta G, Mandal BK, Chowdhury TR, Chanda CR, Chowdhury PP, et al. Arsenic in groundwater in six districts of West Bengal, India. Environ Geochem Health. 1996;18(1):5-15.

93. Mandal BK, Chowdhury TR, Samanta G, et al. Impact of safe water for drinking and cooking on five arsenic-affected families for 2 years in West Bengal, India. Sci Total Environ. 1998;218(23): 185-201.

94. Akai J, Izumi K, Fukuhara H, Masuda H, Nakano S, Yoshimura Ohfuji $\mathrm{H}$, et al. Mineralogical and geomicrobiological investigations on groundwater arsenic enrichment in Bangladesh. Appl Geochem. 2004;19:215-30.

95. Polizzotto ML, Harvey CF, Sutton SR, Fendorf S. Processes conducive to the release and transport of arsenic into aquifers of Bangladesh. Proc Natl Acad Sci U S A. 2005;102:18819-23.

96. Burgess WG, Hoque MA, Michael HA, Voss CI, Breit GN, Ahmed KM. Vulnerability of deep groundwater in the Bengal aquifer system to contamination by arsenic. Nat Geosci. 2010;3: 83-7.

97. Fazal MA, Kawachi T, Ichion E. Validity of the latest research findings on causes of groundwater Arsenic contamination in Bangladesh. Water Int. 2001;26(2):380-9.

98. Meharg AA, Rahman M. Arsenic contamination of Bangladesh paddy field soils: implications for rice contribution to arsenic consumption. Environ Sci Technol. 2003;37:229-34. 
99. Ali MM, Ishiga H, Wakatsuki T. Influence of soil type and properties on distribution and changes in arsenic contents of different paddy soils in Bangladesh. Soil Sci Plant Nutr. 2003;49:111-23.

100. Stummeyer J, Marchig V, Knabe W. The composition of suspended matter from Ganges-Brahmaputra sediment dispersal system during low sediment transport season. Chem Geol. 2002;185:125-47.

101. JICA (Japan International Cooperation Agency). The study on the ground water development of deep aquifers for safe drinking water supply to arsenic affected areas in Western Bangladesh. Draft final report, Japan International Cooperation Agency, Kokusai Kogyo and Mitsui Mineral Development Engineering; 2002.

102. Crecelius EA, Bothner MH, Carpenter R. Geochemistries of arsenic, antimony, mercury, and related elements in sediments of Puget Sound. Environ Sci Technol. 1975;9:325-33.

103. Sullivan KA, Aller RC. Diagenetic cycling of arsenic in Amazon shelf sediments. Geochim Cosmochim Acta. 1996;60:1465-77.

104. Waslenchuk DG. The geochemical controls on arsenic concentrations in south-eastern United States rivers. Chem Geol. 1979;24: 315-25.

105. Datta S, Mallioux B, Jung H, et al. Mineralogy and mobility of Fe and as in Meghna river sediments in Bangladesh. Abstract B24B04. EOS Trans Am Geophys Union. 2005;86(52).

106. Foster AL, Perkins RB, Breit GN, et al. High arsenic accumulation in iron phases in near-surface sediments from Eastern Bangladesh. Abstracts with programs. Geol Soc Am. 2003;35(6):47.

107. Breit GN, Foster AL, Sanzalone RF, Yount JC, Whitney JW, Welch AH, et al. Arsenic cycling in eastern Bangladesh: the role of phyllosilicates. Geol Soc Am Abst Prog. 2001;32(7):A192.

108. Foster AL, Breit GN, Welch AH, Whitney JW, Yount JC, Islam MS, et al. In-situ identification of arsenic species in soil and aquifer sediment from Ramrail, Brahmanbaria, Bangladesh. EOS Trans Am Geophys Union. 2000;81(48):523.

109. Hasan MA, Ahmed KM, Sracek O, Bhattacharya P, Von Bromssen M, Broms S, et al. Arsenic in shallow groundwater of Bangladesh: investigations from three different physiographic settings. Hydrogeol J. 2007;15:1507-22.

110. CGWB. Hydrogeological atlas of West Bengal, Scale 1:2,000,000. Central Ground Water Board (CGWB). Eastern Region: Government of India; 1994.

111. BADC. Final report of the Deep Tubewell II Project, vol 2.1: Natural Resources. Mott Macdonald Ltd and HuntingTechnical Services. Report produced for Bangladesh Agricultural Development Corporation and the Overseas Development Administration. 1992

112. Roychowdhury T, Uchino T, Tokunaga H, Ando M. Effect of arsenic contaminated irrigation water on agriculture land soil and plants in West Bengal, India. Chemosphere. 2005:58:799-810.

113. Roberts LC, Hug SJ, Dittmar J, Voegelin A, Saha GC, Ali MA, et al. Spatial distribution and temporal variability of arsenic in irrigated rice fields in Bangladesh. 1. Irrigation water. Environ Sci Technol. 2007;41:5960-6.

114. Dittmar J, Voegelin A, Roberts LC, Hug SJ, Saha GC, Ali MA, et al. Spatial distribution and temporal variability of arsenic in irrigated rice fields in Bangladesh. 2. Paddy soil. Environ Sci Technol. 2007;41:5967-72.

115. Roberts LC, Hug SJ, Dittmar J, Voegelin A, Kretzschmar R, Wehrli B, et al. Arsenic release from paddy soils during monsoon flooding. Nat Geosci. 2010;3:53-9.

116. Biswas A, Majumder S, Neidhardt H, Halder D, Bhowmick S, Mukherjee-Goswami A, et al. Groundwater chemistry and redox processes: depth dependent arsenic release mechanism. Appl Geochem. 2011;26:516-25.

117. Dowling CB, Poreda RJ, Basu AR, Peters SL, Aggarwal PK. Geochemical study of arsenic release mechanisms in the Bengal Basin groundwater. Water Resour Res. 2002;38:1173-90.
118. Ravenscroft P, McArthur JM, Hoque B. Geochemical and palaeohydrological controls on pollution of groundwater by arsenic. In: Chappell WR, Abernathy CO, Calderon RL, editors. Arsenic exposure and health effects IV. Oxford: Elsevier Science Ltd; 2001. p. 53-77.

119. Routh J, Bhattacharya P, Jacks G, Ahmed KM, Khan AA, Rahman MM. Arsenic geochemistry of Tala groundwater and sediments from Satkhira District, Bangladesh. EOS Trans Am Geophys Union. 2000;81:550

120. Stuben D, Berner Z, Chandrasekharam D, Karmakar J. Arsenic enrichment in groundwater of West Bengal, India: geochemical evidence for mobilization of As under reducing conditions. Appl Geochem. 2003;18:1417-34.

121. Zheng Y, Stute M, van Geen A, Gavrieli I, Dhar R, Simpson HJ, et al. Redox control of arsenic mobilization in Bangladesh groundwater. Appl Geochem. 2004;19:201-14.

122. Ahmed KM, Hoque M, Hasan MK, Ravenscroft P, Chowdhury LR. Origin and occurrence of water well methane gas in Bangladesh aquifers. J Geol Soc India. 1998;51:697-708.

123. Bhattacharya P, Jacks G, Ahmed KM, Khan AA, Routh J. Arsenic in groundwater of the Bengal Delta Plain aquifers in Bangladesh. Bull Environ Contam Toxicol. 2002;69:538-45.

124. Nath B, Sahu SJ, Jana J, Mukherjee-Goswami A, Roy S, Sarkar MJ, et al. Hydrochemistry of arsenic enriched aquifer from rural West Bengal, India: a study of arsenic exposure and mitigation option. Water Air Soil Pollut. 2008;190:95-113.

125. Islam FS, Gault AG, Boothman C, Polya DA, Charnock JM, Chatterjee $\mathrm{D}$, et al. Role of metal-reducing bacteria in arsenic release from Bengal delta sediments. Nature. 2004;430:68-71.

126. Sracek A, Bhattacharaya P, Jacks G, Chatterjee D, Larson M, Leiss A. Groundwater As in the Bengal Delta Plains: a sedimentary geochemical overview. In: Int. Seminar Applied Hydrochemistry. Tamil Nadu, India: Annamalai Univ.; 1998. $18-20$.

127. van Geen A, Zheng Y, Goodbred S, Horneman A, Aziz Z, Cheng $\mathrm{M}$, et al. Flushing history as a hydrogeological control on the regional distribution of arsenic in shallow groundwater of the Bengal Basin. Environ Sci Technol. 2008;42:2283-8.

128. Welch AH, Lico MS. Factors controlling As and $U$ in shallow groundwater, Southern Carson desert, Nevada. Appl Geochem. 1998;13:521-39.

129. Zheng Y, van Geen A, Stute M, Dhar R, Mo Z, Cheng Z, et al. Geochemical and hydrogeological contrasts between shallow and deeper aquifers in two villages of Araihazar, Bangladesh: implications for deeper aquifers as drinking water sources. Geochim Cosmochim Acta. 2005;69:5203-18.

130. Cumming DE, Caccavo Jr F, Fendorf S, Rosenzweig RF. Arsenic mobilization by the dissimilatory Fe(III)-reducing bacterium Shewanella alga BrY. Environ Sci Tech. 1999;33(5):723-9.

131. Langner HW, Inskeep WP. Microbial reduction of arsenate in the presence of ferrihydrite. Environ Sci Technol. 2000;34:3131-6.

132. Dhar RK, Zheng Y, Radloff KA, Mailloux B, Ahmed KM, van Geen A. Microbes enhance mobility of arsenic in Pleistocene aquifer sand from Bangladesh. Environ Sci Tech. 2011;45(7): 2648-54.

133. Ahmann D, Krumholz LR, Hemond HF, Lovley DR, Morel FMM. Microbial mobilization of arsenic from sediments of the Aberjona watershed. Environ Sci Technol. 1997;31:2923-30.

134. Routh J, Saraswathy A. Microbial processes and arsenic mobilization in mine tailings and shallow aquifers. In: Bundschuh $\mathrm{J}$, Bhattacharya $\mathrm{P}$, Chandrashekram C, editors. Natural arsenic in groundwater. Rotterdam: Balkema Publishers; 2005. p. 145-54.

135. Routh J, Saraswathy A, Nag SK, Sinha Ray SP, Jacks G. Arsenic reduction by indigenous bacteria in shallow aquifers from Ambikanagar, West Bengal (India). In: O'Day PA, Vlassopoulos D, Meng X, Benning LG, editors. Advances in arsenic research. 
Integration of experimental and observational studies and implications for mitigation, ACS Symp. Series, 915. Washington: American Chemical Society; 2005. p. 132-47.

136. Routh J, Saraswathy A, Collins MD. Arsenicicoccus bolidensis a novel arsenic reducing actinomycete in contaminated sediments near the Adak mine (Northern Sweden): impact on water chemistry. Sci Total Environ. 2007;379:216-25.

137. Routh J, Bhattacharya A, Saraswathy A, Jacks G, Bhattacharya P. Arsenic remobilization from sediments contaminated with mine tailings near the Adak mine in Västerbotten district (northern Sweden). J Geochem Explor. 2007;92:43-54.

138. Routh J, Hjelmquist P. Distribution of arsenic and its mobility in shallow aquifer sediments from Ambikanagar, West Bengal, India. Appl Geochem. 2011;26:505-15.

139. Macur RE, Wheeler JT, McDermott TR, Inskeep WP. Microbial populations associated with the reduction and enhanced mobilization of arsenic in mine tailings. Environ Sci Technol. 2001;35: 3676-82.

140. Oremland RS, Stolz JF. The ecology of arsenic. Science. 2003;300:939-44.

141. Jones CA, Langner HW, Anderson K, McDermott TR, Inskeep WP. Rates of microbially mediated arsenate reduction and solubilization. Soil Sci Soc Am J. 2000;64:600-8.

142. Sohrin Y, Matsui M, Kawashima M, Hojo M, Hasegawa H. Arsenic biogeochemistry affected by eutrophication in Lake Biwa, Japan. Environ Sci Technol. 1997;31:2712-20.

143. Newman DK, Ahmann D, Morel FMM. A brief review of microbial arsenate respiration. Geomicrobiol J. 1998;15:255-68.

144. Dixit S, Hering JG. Comparison of arsenic(V) and arsenic(III) sorption onto iron oxides minerals: implications for arsenic mobility. Environ Sci Technol. 2003;18:4182-9.

145. Inskeep WP, McDermott TR, Fendorf S. Arsenic(V)/(III) cycling in soils and natural waters: chemical and microbiological processes. In: Frankenberger WT Jr, editor. Environmental chemistry of arsenic. Marcel Dekker; 2002. p. 183-21.

146. Yamazaki C, Ishiga H, Dozen $\mathrm{K}$, et al. Geochemical compositions of sediments of Ganges delta of Bangladesh -arsenic release from peat? Earth Sci. 2000;54:81-93.

147. Neumann RB, Ashfaque KN, Badruzzaman ABM, Ali MA, Shoemaker J, Harvey CF. Anthropogenic influences on groundwater arsenic concentrations in Bangladesh. Nat Geosci. 2010;3: 46-52.

148. Pal T, Mukherjee PK, Sengupta S. Nature of arsenic pollutants in groundwater of Bengal basin - a case study from Baruipur area, West Bengal, India. Curr Sci. 2002;82(5):554-61.

149. Karim M, Komori Y, Alam M. Arsenic occurence and depth of contamination in Bnagladesh. J Environ Chem. 1997;7:783-92.

150. Datta S, Mailloux B, Jung HB, Hoque MA, Stute M, Ahmed KM. Redox trapping of arsenic during groundwater discharge in sediments from the Meghna riverbank in Bangladesh. 2009;16930 16935/PNAS/vol. 106/no. 40.

151. Mukherjee A, Bhattacharya P, Shi F, Fryar AE, Mukherjee AB, $\mathrm{Xie} Z \mathrm{ZM}$, et al. Chemical evolution in high arsenic groundwater in Huhhot basin, Inner Mongolia, P.R. China and its difference from Western Bengal basin, India. Appl Geochem. 2009;24:1835-51.

152. Lawson M, Polya DA, Boyce AJ, Bryant C, Mondal D, Shantz A, et al. Pond-derived organic carbon driving changes in arsenic hazard found in Asian groundwaters. Environ Sci Technol. 2013;47: 7085-94. doi:10.1021/es400114q.

153. Rowland HAL, Polya DA, Lloyd JR, Pancost RD. Characterisation of organic matter in a shallow, reducing, arsenic-rich aquifer, West Bengal. Org Geochem. 2006;37: 1101-14.

154. Oremland RS, Newman DK, Kail BW, Stolz JF. Bacterial respiration of arsenate and its significance in the environment. In:
Frankenberger WT Jr, editor. Environmental chemistry of arsenic. New York: Marcel Dekker; 2002. p. 273-95.

155. Mallick S, Rajgopal NR. Groundwater development in the arsenic affected alluvial belt of West Bengal - some questions. Curr Sci. 1995;70(11):956-8.

156. Appelo CAJ, Van Der Weiden MJJ, Tournassat C, Charlet L. Surface complexation of ferrous iron and carbonate on ferrihydrite and the mobilization of arsenic. Environ Sci Technol. 2002;36: 3096-103.

157. Stollenwerk KG, Breit NG, Welch AH, Yount JC, Whitney JW, Foster AL, et al. Arsenic attenuation by oxidized aquifer sediments in Bangladesh. Sci Total Environ. 2007;379:133-50.

158. Waltham CA, Eick MJ. Kinetics of arsenic adsorption on goethite in the presence of sorbed silicic acid. Soil Sci Soc Am J. 2002;66: 818-25.

159. NRECA. Study of the Impact of the Bangladesh rural electrification program on groundwater quality. Bangladesh Rural Electrification Board. NRECA International with The Johnson Company (USA) and ICDDR, B (Bangladesh); 1997.

160. Bostick BC, Fendorf S. Arsenite sorption on troilite (FeS) and pyrite (FeS2). Geochim Cosmochim Acta. 2003;67:909-21.

161. Savage KS, Tingle TN, O'Day PA, Waychunas GA, Bird DK. Arsenic speciation in pyrite and secondary weathering phases, mother lode gold district, Tuolumne County, California. Appl Geochem. 2000;15:1219-44.

162. Stollenwerk KG, Welch AH, Breit GN. Geochemical processes controlling transport of arsenic in groundwater of Bangladesh. Book of Abstr 6th Int Symp Environ Geochem. Scotland: Edinburgh; 2003.

163. Welch AH, Stollenwerk KG, Breit GN, Foster AL, Yount JC, Whitney JW, et al. Attenuation of arsenic in Bangladesh sediments. Implications for groundwater development. In: Naidu R, Smith E, Owens G, Bhattacharya P, Nadebaum P, editors. Managing arsenic in the environment: from soil to human health. Collingwood: CSIRO Publishing; 2006. p. 363-77.

164. Oscarson DW, Huang PM, Liaw WK. The oxidation of arsenite by aquatic sediments. J Environ Qual. 1980;9:700-3.

165. Shamsudduha M, Uddin LJMA, Lee M-K, Saunders JA. Spatial relationship of groundwater arsenic distribution with regional topography and water-table fluctuations in the shallow aquifers in Bangladesh. Environ Geol. 2009;57:1521-35.

166. Weinman B, Goodbred S, Zheng Y, Aziz Z, Steckler M, van Geen $\mathrm{A}$, et al. Contributions of floodplain stratigraphy and evolution to the spatial patterns of groundwater arsenic in Araihazar, Bangladesh. Geol Soc Am Bull. 2008;120:1567-80.

167. McArthur JM, Ravenscroft P, Banerjee DM, Milsom J, Hudson Edwards KA, Sengupta S, et al. How paleosols influence groundwater flow and arsenic pollution: a model from the Bengal Basin and its worldwide implication. Water Resour Res. 2008;44: W11411.

168. van Geen A, Ahmed KM, Akita Y, Alam MJ, Culligan PJ, Emch $\mathrm{M}$, et al. Fecal contamination of shallow tubewells in Bangladesh inversely related to arsenic. Environ Sci Technol. 2011;45:1199205.

169. Klump S, Kipfer R, Olaf AC, Harvey CF, Brennwald MS, Khandkar NA, et al. Groundwater dynamics and arsenic mobilization in Bangladesh assessed using noble gases and tritium. Environ Sci Technol. 2006;40:243-50.

170. Sikdar PK, Sarkar SS, Palchoudhury S. Geochemical evolution of groundwater in the quaternary aquifer of Calcutta and Howrah, India. J Asian Earth Sci. 2001;19:579-94.

171. Das D, Chatterjee A, Mandal BK, Samanta G, Chakraborti D, Chanda B. Arsenic in groundwater in six districts of West Bengal, India: the biggest arsenic calamity in the world. Part 2: Arsenic concentration in drinking water, hair, nails, urine, 
skinscale and liver tissue (biopsy) of the affected people. Analyst. 1995;120:917-24.

172. Harvey CF, Swartz C, Badruzzman ABM, Keon-Blute N, Yu W, Ali MA, et al. Response to comments on arsenic mobility and groundwater extraction in Bangladesh. Science. 2003;300(5619): 584.

173. Cuthbert M, Burgess WG, Connell L. Constraints on the sustainable development of arsenic-bearing aquifers in southern Bangladesh. Part 2: preliminary models of arsenic variability in groundwater. In: Hiscock KM, Rivett MO, Davison RM, editors. Sustainable groundwater development. Geological Society, London, Special Publication 2002;193:165-17.

174. Mukherjee A. Deeper groundwater chemistry and flow in the arsenic affected Western Bengal Basin, West Bengal, India. Dissertation. Lexington: University of Kentucky; 2006. p. 248.
175. Radloff KA, Zheng Y, Michael HA, Stute M, Bostick BC, Mihajlov I, et al. Arsenic migration to deep groundwater in Bangladesh influenced by adsorption and water demand. Nat Geosci. 2011;4:793-8.

176. Michael HA, Voss CI. Evaluation of the sustainability of deep groundwater as an arsenic-safe resource in the Bengal Basin. PNAS. 2008;105(25):8531-6.

177. Burren M. Small-scale variability of arsenic in groundwater in the District of Meherpur, Western Bangladesh. MSc Thesis (unpub), University College London; 1998.

178. McArthur JM, Sikdar PK, Hoque MA, Ghosal U. Waste-water impacts on groundwater: $\mathrm{Cl} / \mathrm{Br}$ ratios and implications for arsenic pollution of groundwater in the Bengal Basin and Red River Basin, Vietnam. Sci Total Environ. 2012;437:390-402. 